\title{
Temporary reduction in air pollution due to anthropogenic activity switch-off during COVID-19 lockdown in northern parts of India
}

\author{
Alok Sagar Gautam ${ }^{1}$ - Nikhilesh Kumar Dilwaliya ${ }^{2}$ Ayushi Srivastava ${ }^{3}$. \\ Sanjeev Kumar ${ }^{1} \cdot K^{\prime}$ uldeep Bauddh ${ }^{4} \cdot$ Devendraa Siingh $^{5} \cdot$ M. A. Shah ${ }^{2} \cdot K^{\prime}$ aran Singh ${ }^{1}$. \\ Sneha Gautam ${ }^{6}$
}

Received: 1 September 2020 / Accepted: 16 September 2020 / Published online: 24 September 2020

(c) Springer Nature B.V. 2020

\begin{abstract}
Due to fast and deadly spread of corona virus (COVID-19), the Government of India implemented lockdown in the entire country from 25 April 2020. So, we studied the differences in the air quality index (AQI) of Delhi (DTU, Okhla and Patparganj), Haryana (Jind, Palwal and Hisar) and Uttar Pradesh (Agra, Kanpur and Greater Noida) from 17 February 2020 to 4 May 2020. The AQI was calculated by combination of individual sub-indices of seven pollutants, namely $\mathrm{PM}_{2.5}, \mathrm{PM}_{10}, \mathrm{NO}_{2}, \mathrm{NH}_{3}, \mathrm{SO}_{2}, \mathrm{CO}$ and $\mathrm{O}_{3}$, collected from the Central Pollution Control Board website. The AQI has improved by up to 30-46.67\% after lockdown. The AQI slope values $-1.87,-1.70$ and -1.35 were reported for Delhi, $-1.11,-1.31$ and -1.04 were observed for Haryana and $-1.48,-1.79$ and -1.78 were found for Uttar Pradesh (UP), which may be attributed to limited access of transportation and industrial facilities due to lockdown. The ozone $\left(\mathrm{O}_{3}\right)$ concentration was high at Delhi because of lesser greenery as compared to UP and Haryana, which provides higher atmospheric temperature favourable for $\mathrm{O}_{3}$ formation. The air mass back trajectory (AMBT) analysis reveals the contribution of air mass from Europe, Africa and Gulf countries as well as local emissions from Indo-Gangetic Plain, Madhya Pradesh and Maharashtra states of India.
\end{abstract}

Keywords AQI · Lockdown · CPCB · Pollutants · Air mass back trajectory

Alok Sagar Gautam

phyalok@gmail.com

Sanjeev Kumar

sk8190179@gmail.com

$\triangle$ Sneha Gautam

snehagautam@karunya.edu

Extended author information available on the last page of the article 


\section{Introduction}

The influenza pandemic since the sixteenth century is known to occur twice or thrice every century (Potter 2001). In the twentieth century, the Spanish flu (1918), the Asian flu (1957) and the Hong Kong flu (1968) were reported, in which the Spanish flu originated by the H1N1 virus turned out to be the deadliest of all, killing 21-50 million people (Gottfredsson et al. 2008).

The COVID-19 pandemic (Driggin et al. 2020) originated in Wuhan, China, where the patient zero was in December 2019 (Culp 2020). COVID-19 is a single-stranded RNA virus, size ranging from 26 to 32 kilobases (Shereen et al. 2020). Its genome is highly identical to the bat's genome, suggesting them to be its natural host. The transmission of the virus is through respiratory droplets which occur upon close contact to an infected person or via droplets fallen on the surface (Güner et al. 2020).

Since the disease occurred through human-to-human transmission (Huang et al. 2020), it soon spread to other parts of China. Considering this, the government implemented a lockdown in Wuhan on January 23, 2020. The countries, including India, evacuated their citizens from Wuhan, brought them back via special flights and quarantined them for 14 days (Singhal 2020).

The patient zero of COVID-19 was reported in Kerala (India) on January 30, 2020, (Sarkar et al. 2020). The number of cases reported as on 22 March 2020 6:30 pm IST was 360 including 319 Indians and 41 foreigners (WHO 2020). The Prime Minister of India declared a 'Janata-Curfew (voluntary curfew or self-imposed lockdown by people without any penal action)' on 22 March 2020 (7:00 a.m. to 9:00 p.m., IST) and lockdown from 25 March to 14 April 2020 to 'break the chain' to stop the spread. Lockdown was extended from 15 April to 3 May 2020 (Gautam and Hens 2020; Mitra et al. 2020).

Zoran et al. (2020) establish a link between the coronavirus and air pollution suggesting that the pollutants $\left(\mathrm{PM}_{10}\right.$ and $\left.\mathrm{PM}_{2.5}\right)$ possibly attached with viruses and bacteria, which can be transported deep into the respiratory tract crossing the mechanical barriers attributing to a high risk of inflammation and hyper-responsiveness which may have a negative impact on the immune system. Zhu et al. (2020) also claimed that the higher concentration of $\mathrm{PM}_{2.5}, \mathrm{PM}_{10}, \mathrm{CO}, \mathrm{NO}_{2}$ and $\mathrm{O}_{3}$ can increase the risk of COVID19 infection.

After the lockdown, self-quarantine measures were enforced, resulting in less human mobility. Thus, the pollution caused as a result of anthropogenic activities was reduced significantly especially air pollution. The harmful pollutants emanated from industries, transportation, etc., were reduced to a remarkable level, thereby resulting in the cleansing of the environment (Sharma et al. 2020). Srivastava et al. (2020) also observed a significant decline in the concentration of atmospheric pollutants $\mathrm{PM}_{2.5}, \mathrm{NO}_{2}, \mathrm{SO}_{2}$ and CO before lockdown (21 days) and after lockdown (21 days) over Delhi and Lucknow.

Based on literature review, we conclude that Haryana and Uttar Pradesh (UP) were not fully explored and compare with Delhi (one of the most polluted states of India). In this manuscript, three different locations from each state (Delhi, UP and Haryana) were consider along with two novel sites, Palwal and Hisar of Haryana. Further, air mass back trajectory (Sect. 3.5) analysis was performed to identify the origin of pollutants for the selected monitoring stations during 17 February 2020 to 4 May 2020. The details of site are also provided in Sect. 2.1. 


\section{Methodology and techniques}

\subsection{Site description}

Delhi (most polluted region of India) was considered for this study along with its surrounding states Haryana (agricultural stubble burning is practiced at a large scale and also a well-developed industrial state) and UP (most populated state contributing greatly to air pollution due to anthropogenic activities). We picked three locations from each of these regions (total 9 monitoring stations), Jind, Palwal and Hisar from Haryana; Agra, Kanpur and Greater Noida from UP, and Delhi Technical University (DTU), Okhla and Patparganj (PJ) from Delhi (Fig. 1).

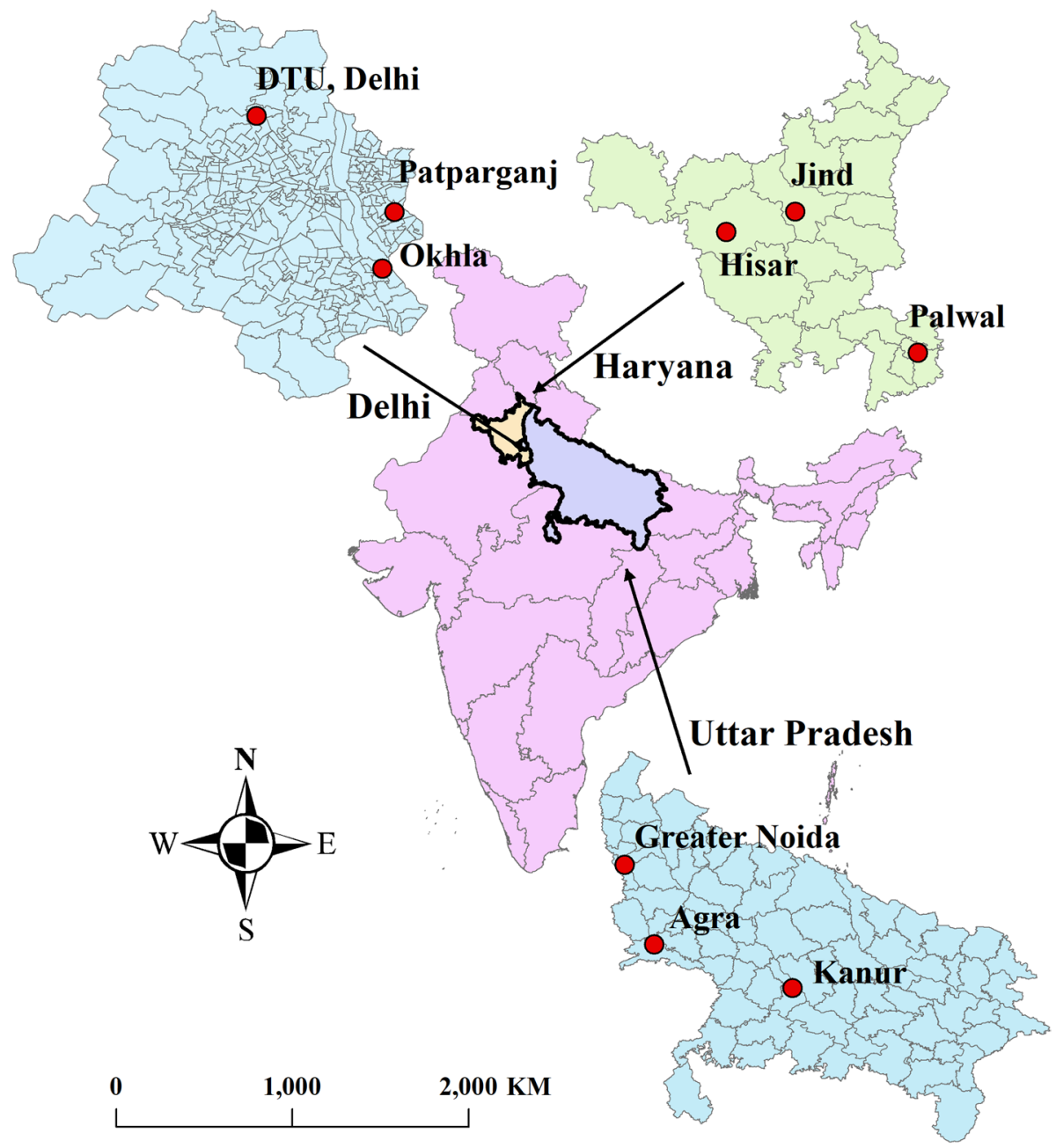

Fig. 1 Location of monitoring stations in Delhi (Okhla, DTU, Patparganj), Haryana (Palwal, Jind, Hisar) and Uttar Pradesh (Agra, Kanpur, Greater Noida). Source: Based on QGIS dataset 


\subsubsection{Delhi}

It is known to have inhabited since sixth century BC. It is the national territory of India and was converted into union territory in the year 1956. The area of Delhi is $1483 \mathrm{~km}^{2}$ (Micro, Small, Medium Enterprises Development Institute-Government of India (MSMEDI-GOI) 2012). Being the capital territory, the area is densely populated with a population of over 3 crores. The forest cover of Delhi is $20.20 \%$; the industrial cover is $12 \%$ of the total area (MSME-DI-GOI 2012). The major sources of pollution are transportation, industries, power plants (Badarpur Thermal Power Station) and the burning of garbage. The pollution level reaches at its peak during November-December due to heavy metal-rich smoke of firecrackers (Sawlani et al. 2019).

\subsubsection{Haryana}

It is the leading contributor of Basmati rice (62\%) in India (NCML 2019; Erenstein 2010). It surrounds Delhi on 3 sides. Its capital Chandigarh is shared with Punjab. The area of Haryana is $44,212 \mathrm{~km}^{2}$, and its population is over 2.5 crores. The maximum area of the state is used for cultivation purposes, i.e. $84 \%$ of the total area. The forest cover of Haryana is $4 \%$ (MSME-DI-GOI 2015). The major sources of pollution include vehicular emission, garbage burning, agricultural stubble burning and construction dust.

\subsubsection{Uttar Pradesh (UP)}

It is the most populous state of India with a population of over 22.45 crores, i.e. approx. $17 \%$ of the total population of India (UIAI-GOI 2017) with area of 2,43,290 $\mathrm{km}^{2}$. Forest cover is $16,582 \mathrm{~km}^{2}$ (Anon 2017). The major sources of air pollution in UP are industrial emission, transportation, waste and garbage burning and road dust. Industrial emission is the biggest cause of pollution in Kanpur.

\subsection{Description of the data set}

Although the National Ambient Air Quality standards are usually taken for $\mathrm{PM}_{10}, \mathrm{PM}_{2.5}$, $\mathrm{NO}_{2}, \mathrm{SO}_{2}, \mathrm{CO}, \mathrm{O}_{3}, \mathrm{NH}_{3}, \mathrm{~Pb}, \mathrm{Ni}$, As, benzo (a) pyrene and benzene (Akolkar 2016), the data are taken here only for the pollutants, $\mathrm{PM}_{2.5}, \mathrm{PM}_{10}, \mathrm{NO}_{2}, \mathrm{NH}_{3}, \mathrm{SO}_{2}$ and $\mathrm{O}_{3}$ in $\mu \mathrm{g} /$ $\mathrm{m}^{3}$ and for $\mathrm{CO}$ in $\mathrm{mg} / \mathrm{m}^{3}$ from Central Pollution Control Board (CPCB) website (https:// app.cpcbccr.com/AQI_India/). The pollutants $\mathrm{PM}_{2.5}, \mathrm{PM}_{10}, \mathrm{NO}_{2}, \mathrm{NH}_{3}, \mathrm{SO}_{2}$ have a standard average of $24 \mathrm{~h}$, whereas the pollutants $\mathrm{O}_{3}$ and $\mathrm{CO}$ have a standard average of $8 \mathrm{~h}$, i.e. data taken at 12:00 PM on 10 April 2020 of $\mathrm{PM}_{2.5}$ will be an average of hourly data taken for last $24 \mathrm{~h}$. The Indian AQI system is defined as deliberation of each and every pollutants on human health, which can be calculated by using two steps involvements: (a) formation of individual sub-indices (SIs) of pollutants and (b) combination of sub-indices to obtain AQI (Akolkar 2016). The SIs $\left(I_{1}, I_{2}, \ldots \ldots, I_{N}\right)$ for $\mathrm{N}$ pollutant $\left(X_{1}, X_{2}, \ldots \ldots, X_{N}\right)$ are calculated by using sub-index functions as follows:

$$
I_{i}=f\left(X_{i}\right),
$$


where $i=1,2, \ldots \ldots, \mathrm{N}$.

Now, aggregation of sub-indices $\left(I_{i}\right)$ is calculated by using the following mathematical function (given below):

$$
I=F\left(I_{1}, I_{2}, \ldots \ldots \ldots \ldots \ldots I_{N}\right)
$$

The sub-index $\left(I_{\mathrm{p}}\right)$ for a known pollutant concentration $\left(C_{\mathrm{p}}\right)$ is given by

$$
I_{\mathrm{p}}=\left[\left\{\frac{I_{\mathrm{HI}}-I_{\mathrm{LO}}}{B_{\mathrm{HI}}-B_{\mathrm{LO}}}\right\} \times\left(C_{\mathrm{p}}-B_{\mathrm{LO}}\right)\right]+I_{\mathrm{LO}}
$$

$B_{\mathrm{HI}}=$ breakpoint concentration greater or equal to given concentration, $B_{\mathrm{LO}}=$ breakpoint concentration smaller or equal to given concentration, $I_{\mathrm{HI}}=\mathrm{AQI}$ value corresponding to $B_{\mathrm{HI}}, I_{\mathrm{LO}}=\mathrm{AQI}$ value corresponding to $B_{\mathrm{LO}}$.

Furthermore, mathematically AQI is given by:

$$
\mathrm{AQI}=\operatorname{MAX}\left(I_{\mathrm{p}}\right)
$$

where $p=1,2 \ldots N$. (Mahato et al. 2020).

The standard value for each pollutant is given in Table 3 (Akolkar 2016). The Indian AQI system has been classified into six categories according to their server range as mention in Table 4.

In UP, data of $\mathrm{PM}_{2.5}, \mathrm{NO}_{2}, \mathrm{SO}_{2}, \mathrm{O}_{3}$ and $\mathrm{CO}$ were available for Agra, whereas $\mathrm{PM}_{2.5}$, $\mathrm{NO}_{2}, \mathrm{SO}_{2}$ and $\mathrm{O}_{3}$ were available for Kanpur. The data for all the considered parameters were extracted and plotted from 17 February 2020 to 4 May 2020. However, data of some pollution parameters were missing on the CPCB website, and the reason could be some technical issues or rainfall. Furthermore, data were plotted to calculate the slope by linear fitting method using student version/trail of Origin Lab 2020b (Serial Number GL3S46089-7,609,063) software (Table 2). The air mass back trajectories were extracted from the National Oceanic and Atmospheric Administration (NOAA), Air Resources Laboratory (ARL) and Hybrid Single-Particle Lagrangian Integrated Trajectory (HYSPLIT) model (Stein et al. 2015) to understand the transportation and origin of pollutants. This analysis was carried out by using Google Map Import application available in Origin Lab software.

\section{Results and discussion}

The AQI levels were high before lockdown period (17 February 2020 to 23 March 2020) which may be due to anthropogenic activities like transportation, industrial emission, burning of household, agricultural and electronic wastes. Figures 2, 3, 4, 5, 6 and 7 reveal a sudden decrease in the levels of pollutants in the before lockdown period on 3 dates 22 February 2020, 01 March 2020 and 09 March 2020 in all the 9 sites, which was due to rainfall/precipitation (Kim et al. 2014) as recorded by Indian Meteorological Department (IMD), Public Weather Bulletin (PWB) (IMD, 22 February 2020a; IMD, 01 March 2020b; IMD, 09 March 2020c).

\subsection{Variation of atmospheric pollutants over Delhi}

The daily average concentration of $\mathrm{PM}_{2.5}$ before (17/02/2020 to 24/03/2020) and after (25/03/2020 to 04/05/2020) lockdown fluctuated from 48 to $348 \mu \mathrm{g} / \mathrm{m}^{3}$ and 43 to 137 

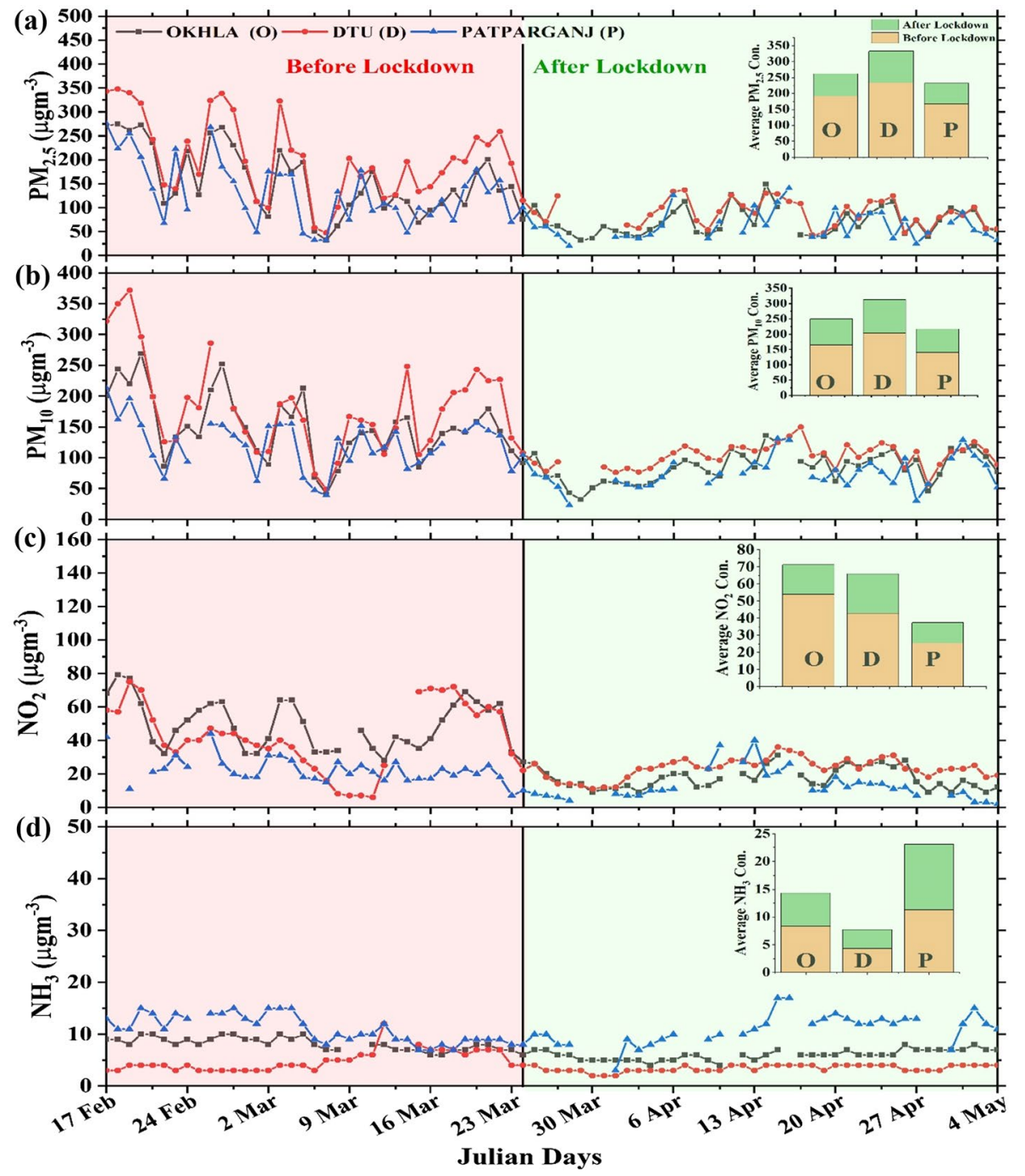

Fig. 2 The variations in levels of pollutants $\left(\mathrm{PM}_{2.5}, \mathrm{PM}_{10}, \mathrm{NO}_{2}, \mathrm{NH}_{3}\right)$ over Delhi during before (17 March 2020 to 24 March 2020) and after lockdown (25 March 2020 to 4 May 2020). Source: Based on CPCB dataset

$\mu \mathrm{g} / \mathrm{m}^{3}$ at DTU. It was observed to vary from 32 to $275 \mu \mathrm{g} / \mathrm{m}^{3}$ and 32 to $149 \mu \mathrm{g} / \mathrm{m}^{3}$ at Okhla, whereas it was reported in the range of 32 to $276 \mu \mathrm{g} / \mathrm{m}^{3}$ and 20 to $141 \mu \mathrm{g} / \mathrm{m}^{3}$ at PJ. Similarly, the variation of $\mathrm{PM}_{10}$ was reported in the range of 49 to $372 \mu \mathrm{g} / \mathrm{m}^{3}$ and 57 to $150 \mu \mathrm{g} / \mathrm{m}^{3}$ over DTU and 41 to $269 \mu \mathrm{g} / \mathrm{m}^{3}$ and 32 to $136 \mu \mathrm{g} / \mathrm{m}^{3}$ over Okhla; however, it was 39 to $213 \mu \mathrm{g} / \mathrm{m}^{3}$ and 23 to $131 \mu \mathrm{g} / \mathrm{m}^{3}$ at PJ before and after lockdown, respectively. For $\mathrm{NO}_{2}$, the values before and after lockdown were reported ranging from 6 to $75 \mu \mathrm{g} / \mathrm{m}^{3}$ and 11 to $36 \mu \mathrm{g} / \mathrm{m}^{3}, 27$ to $79 \mu \mathrm{g} / \mathrm{m}^{3}$ and 9 to $31 \mu \mathrm{g} / \mathrm{m}^{3}$ and 7 to $44 \mu \mathrm{g} / \mathrm{m}^{3}$ and 2 to $40 \mu \mathrm{g} / \mathrm{m}^{3}$ at the above monitoring locations. The level of $\mathrm{NH}_{3}$ did not show a significant variation; the levels before and after the event ranged from 3 to $12 \mu \mathrm{g} / \mathrm{m}^{3}$ and 


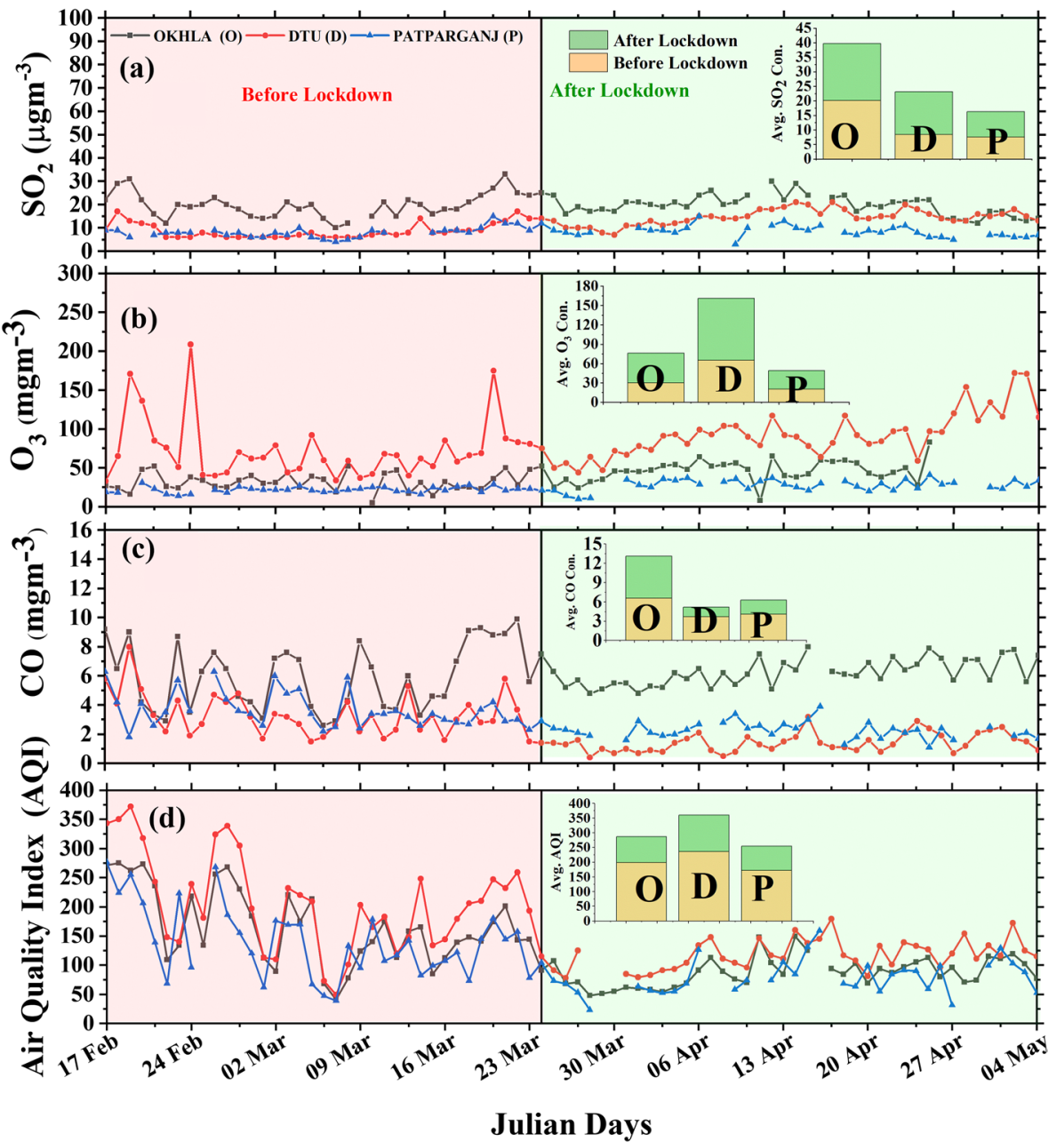

Fig. 3 The variations in levels of pollutants $\left(\mathrm{SO}_{2}, \mathrm{O}_{3}, \mathrm{CO}, \mathrm{AQI}\right)$ over Delhi during before (17 March 2020 to 24 March 2020) and after lockdown (25 March 2020 to 4 May 2020). Source: Based on CPCB dataset

2 to 4,6 to $10 \mu \mathrm{g} / \mathrm{m}^{3}$ and 4 to $8 \mu \mathrm{g} / \mathrm{m}^{3}$ and 7 to $15 \mu \mathrm{g} / \mathrm{m}^{3}$ and 3 to $17 \mu \mathrm{g} / \mathrm{m}^{3}$, respectively. The AQI before and after lockdown was observed from 49 to 372 and 78 to 199,41 to 275 and 48 to 149 and 39 to 276 and 23 to 179 for DTU, Okhla and PJ, respectively. $\mathrm{SO}_{2}$ levels were almost constant varying with small perturbation under the standard (Table 3); however, it shows the before and after lockdown values from 6 to $17 \mu \mathrm{g} / \mathrm{m}^{3}$ and 7 to $21 \mu \mathrm{g} / \mathrm{m}^{3}, 10$ to $33 \mu \mathrm{g} / \mathrm{m}^{3}$ and 12 to $30 \mu \mathrm{g} / \mathrm{m}^{3}$ and 4 to $15 \mu \mathrm{g} / \mathrm{m}^{3}$ and 3 to $15 \mu \mathrm{g} /$ $\mathrm{m}^{3}$ at the selected sites over Delhi before and after lockdown, respectively. The variation in the levels of CO before and after lockdown was recorded as 1.4 to $8 \mathrm{mg} / \mathrm{m}^{3}$ and 0.4 to $3.2 \mathrm{mg} / \mathrm{m}^{3}, 2.6$ to $9.9 \mathrm{mg} / \mathrm{m}^{3}$ and 4.8 to $8 \mathrm{mg} / \mathrm{m}^{3}$ and 1.8 to $6.3 \mathrm{mg} / \mathrm{m}^{3}$ and 1.1 to $3.9 \mathrm{mg} / \mathrm{m}^{3}$, respectively. $\mathrm{O}_{3}$ variations were recorded as before and after lockdown from 33 to $209 \mu \mathrm{g} / \mathrm{m}^{3}$ and 44 to $172 \mu \mathrm{g} / \mathrm{m}^{3}, 5$ to $52 \mu \mathrm{g} / \mathrm{m}^{3}$ and 8 to $83 \mu \mathrm{g} / \mathrm{m}^{3}$ and 14 to $31 \mu \mathrm{g} /$ $\mathrm{m}^{3}$ and 10 to $41 \mu \mathrm{g} / \mathrm{m}^{3}$, respectively. The average values before and after lockdown are given in Table 1. 

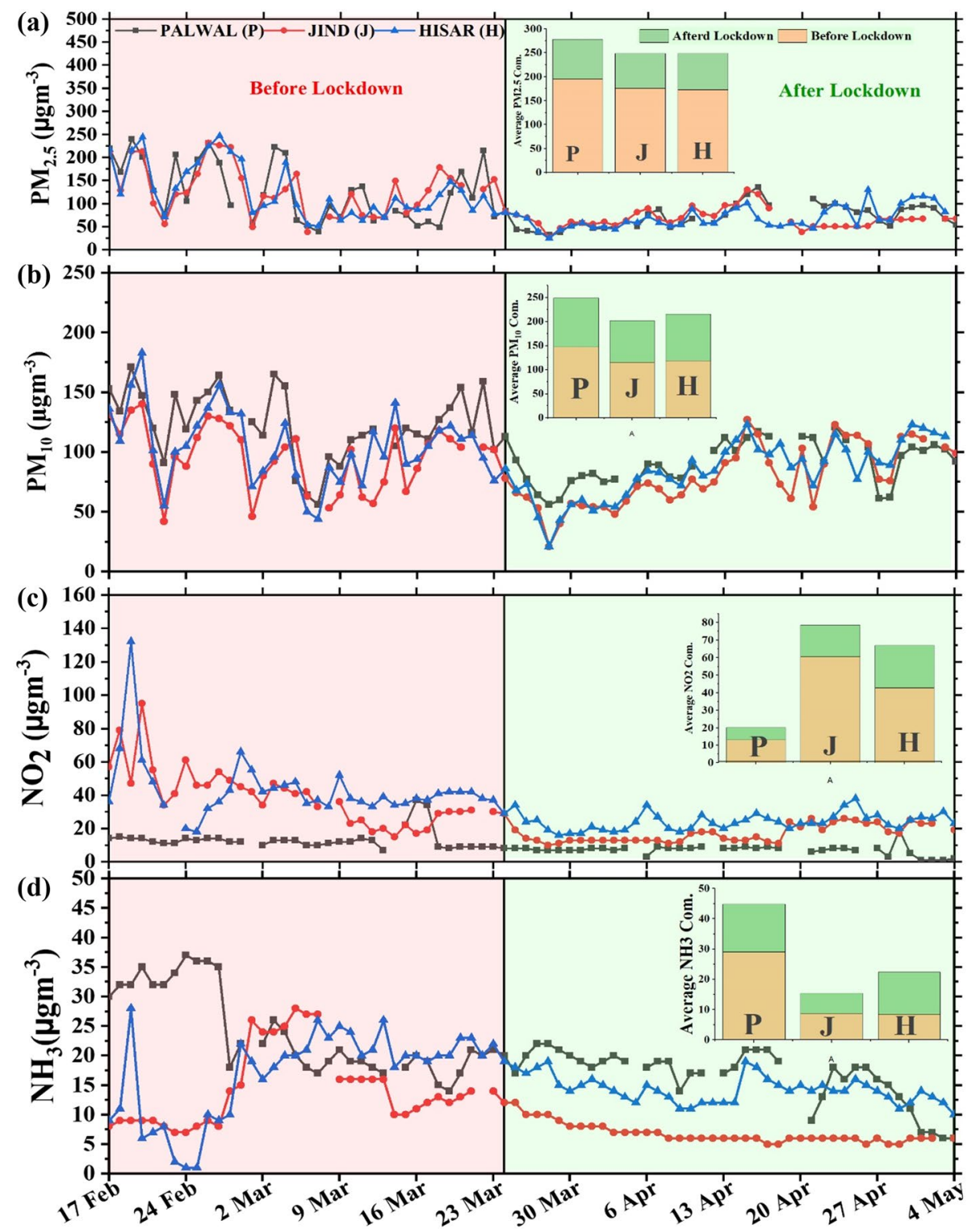

\section{Julian Days}

Fig. 4 The variations in levels of pollutants $\left(\mathrm{PM}_{2.5}, \mathrm{PM}_{10}, \mathrm{NO}_{2}, \mathrm{NH}_{3}\right)$ over Haryana during before (17 March 2020 to 24 March 2020) and after lockdown (25 March 2020 to 4 May 2020). Source: Based on CPCB dataset

The levels of $\mathrm{PM}_{2.5}$ and $\mathrm{PM}_{10}$ in DTU, Okhla and PJ can be seen in Fig. 2a, b fluctuating way above the National Air Quality Standard $60 \mu \mathrm{g} / \mathrm{m}^{3}$ and $100 \mu \mathrm{g} / \mathrm{m}^{3}$, respectively (Table 3). The sudden halt of transportation and industrial activities caused a remarkable decrease in $\mathrm{PM}_{2.5}$ and $\mathrm{PM}_{10}$. The $\mathrm{PM}_{2.5}$ and $\mathrm{PM}_{10}$ were reduced up to $64 \mu \mathrm{g} / \mathrm{m}^{3}, 45 \mu \mathrm{g} /$ 

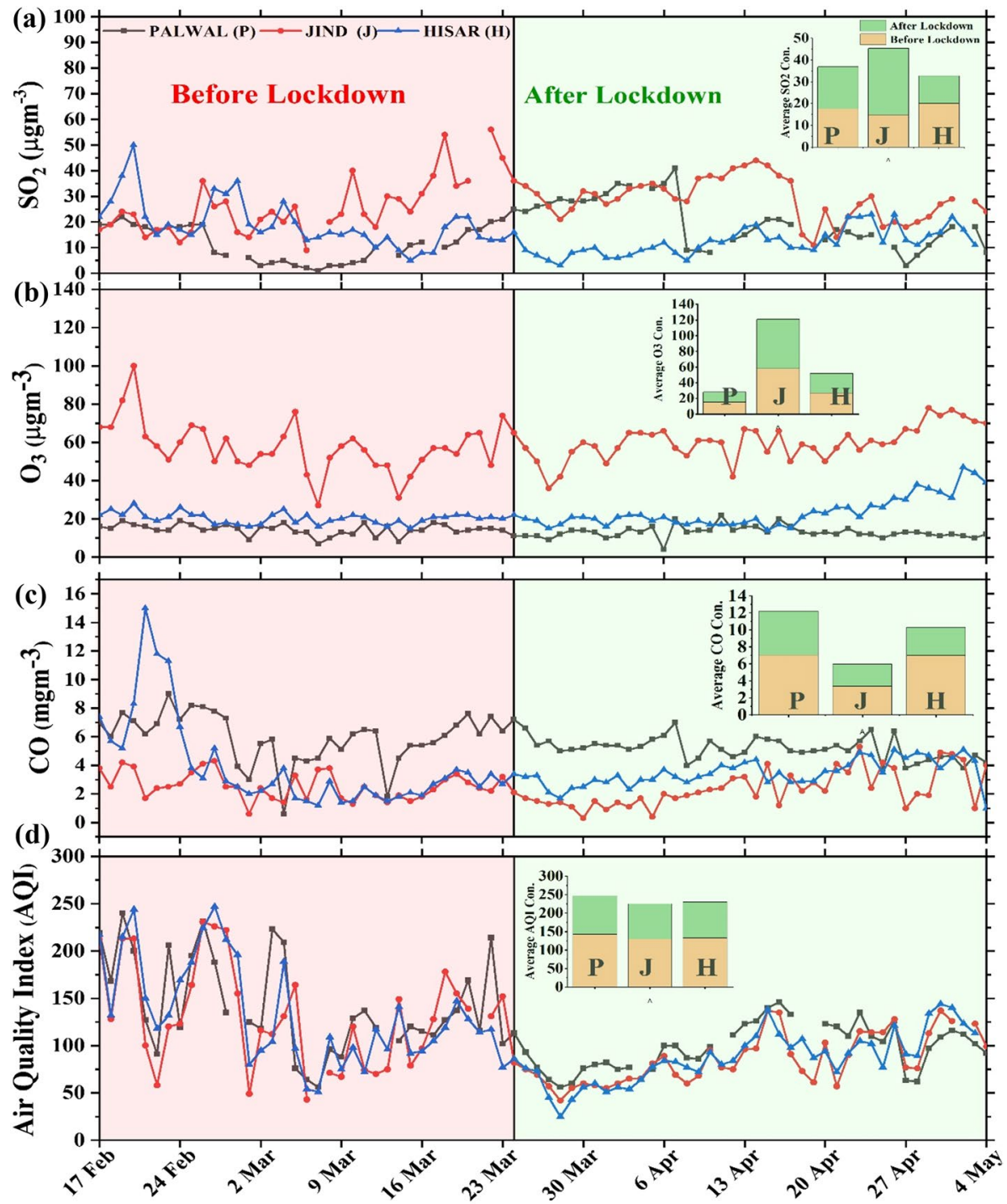

Julian Days

Fig. 5 The variations in levels of pollutants $\left(\mathrm{SO}_{2}, \mathrm{O}_{3}, \mathrm{CO}, \mathrm{AQI}\right)$ over Haryana during before (17 March 2020 to 24 March 2020) and after lockdown (25 March 2020 to 4 May 2020). Source: Based on CPCB dataset

$\mathrm{m}^{3}$ and $40 \mu \mathrm{g} / \mathrm{m}^{3}$ and $83 \mu \mathrm{g} / \mathrm{m}^{3}, 58 \mu \mathrm{g} / \mathrm{m}^{3}$ and $56 \mu \mathrm{g} / \mathrm{m}^{3}$, respectively, on 2 April 2020 . But as soon as the relaxation was given, the curves again took a rise above the standard levels (Table 3) on 14 April 2020 to $130 \mu \mathrm{g} / \mathrm{m}^{3}, 149 \mu \mathrm{g} / \mathrm{m}^{3}$ and $63 \mu \mathrm{g} / \mathrm{m}^{3}$ and $114 \mu \mathrm{g} / \mathrm{m}^{3}$, $136 \mu \mathrm{g} / \mathrm{m}^{3}$ and $84 \mu \mathrm{g} / \mathrm{m}^{3}$, but were lower in comparison with before lockdown. The overall reduction of $\mathrm{PM}_{2.5}$ and $\mathrm{PM}_{10}$ levels can be understood in terms of slope values (Table 2) $-2.77,-2.49$ and -2.13 and $-1.91,-1.45$ and -1.15 for DTU, Okhla and PJ station, 


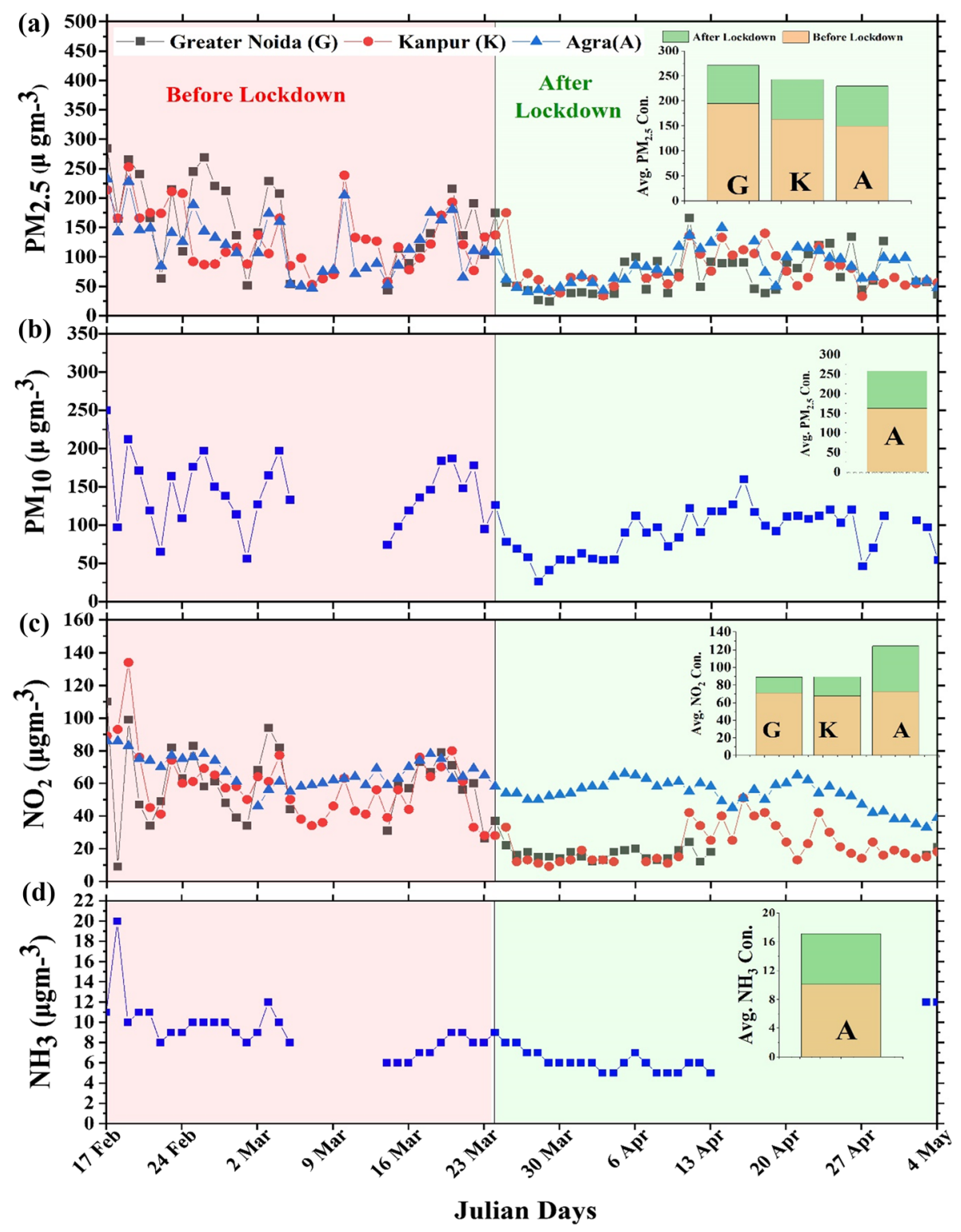

Fig. 6 The variations in levels of pollutants $\left(\mathrm{PM}_{2.5}, \mathrm{PM}_{10}, \mathrm{NO}_{2}, \mathrm{NH}_{3}\right)$ over Uttar Pradesh (UP) during before (17 March 2020 to 24 March 2020) and after lockdown (25 March 2020 to 4 May 2020). Source: Based on CPCB dataset

respectively. The negative slope indicates the decline in the pollution levels (Singh and Chauhan 2020). Similarly, $\mathrm{NO}_{2}$ and $\mathrm{NH}_{3}$ values were also showing the reduction in levels which can be seen in their slope values $-0.30,-0.63$ and -0.27 and $-0.02,-0.04$ and -0.01 , respectively, given Table 2 . The values of $\mathrm{NO}_{2}$ and $\mathrm{NH}_{3}$ just after lockdown were $18 \mu \mathrm{g} / \mathrm{m}^{3}, 13 \mu \mathrm{g} / \mathrm{m}^{3}$ and $7 \mu \mathrm{g} / \mathrm{m}^{3}$ and $3 \mu \mathrm{g} / \mathrm{m}^{3}, 5 \mu \mathrm{g} / \mathrm{m}^{3}$ and $9 \mu \mathrm{g} / \mathrm{m}^{3}$ on 2 April 2020 and 

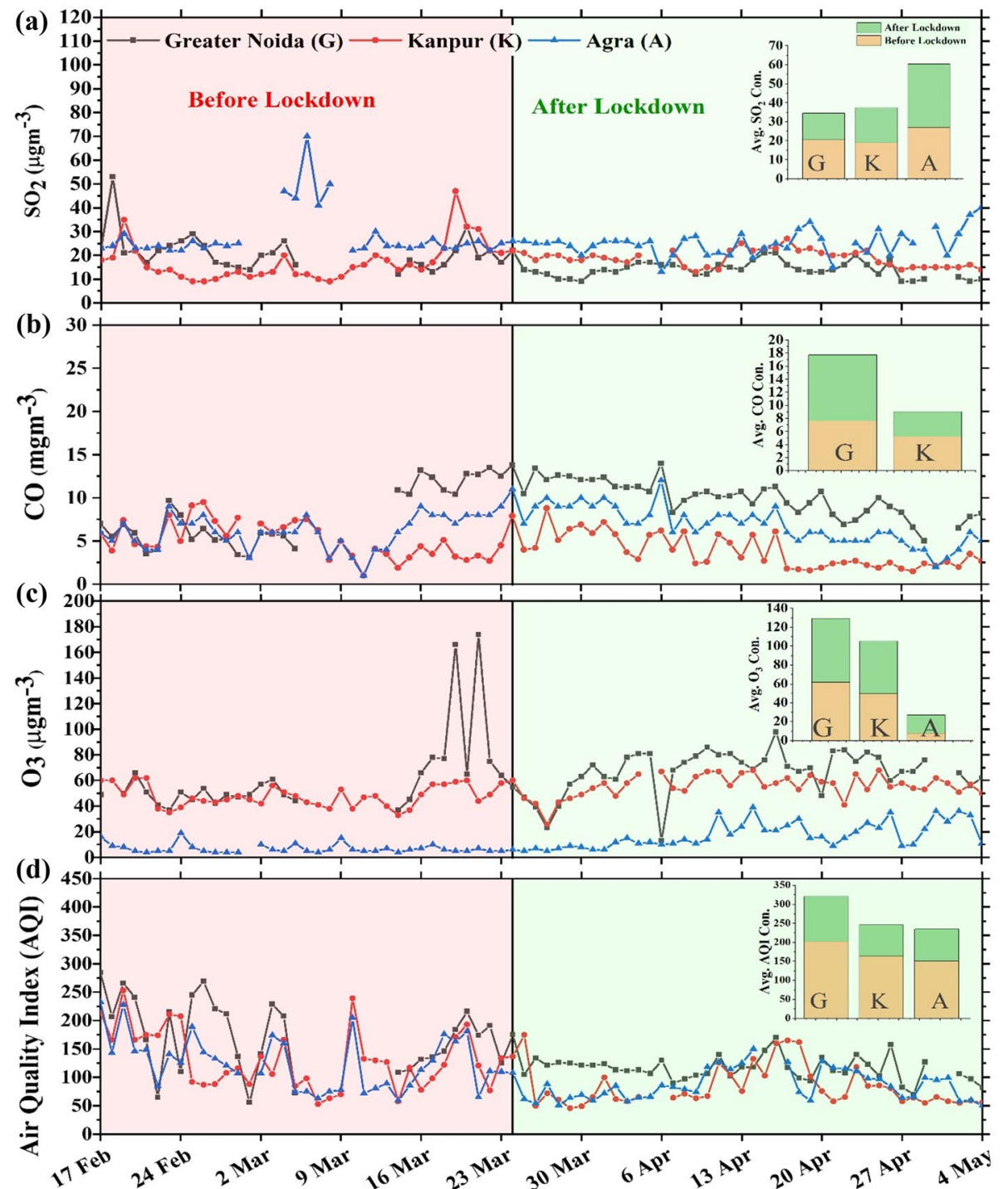

Julian Days

Fig. 7 The variations in levels of pollutants $\left(\mathrm{SO}_{2}, \mathrm{CO}, \mathrm{O}_{3}, \mathrm{AQI}\right)$ over UP during before (17 March 2020 to 24 March 2020) and after lockdown (25 March 2020 to 4 May 2020). Source: Based on CPCB dataset

rise to values $30 \mu \mathrm{g} / \mathrm{m}^{3}, 22 \mu \mathrm{g} / \mathrm{m}^{3}$ and $27 \mu \mathrm{g} / \mathrm{m}^{3}$ and $4 \mu \mathrm{g} / \mathrm{m}^{3}, 7 \mu \mathrm{g} / \mathrm{m}^{3}$ and $17 \mu \mathrm{g} / \mathrm{m}^{3}$ on 16 April 2020 due to dust storm (NDTV, 15 April 2020). The $\mathrm{NO}_{2}$ and $\mathrm{CO}$ concentrations depend upon the combustion practices carried out by industries, power plants and transportation (Mahato et al. 2020). Thus, the same can be seen for CO in Fig. 3c with slope values $-0.04,-0.004$ and -0.04 , which suggests that there is not much change. The lowest values for $\mathrm{CO}$ just after lockdown were recorded as 0.7, 4.8 and 2.9 on 1 April 2020. Majorly, $\mathrm{NH}_{3}$ is emitted as a result of agricultural activities (Tanvir et al. 2019). Emissions 


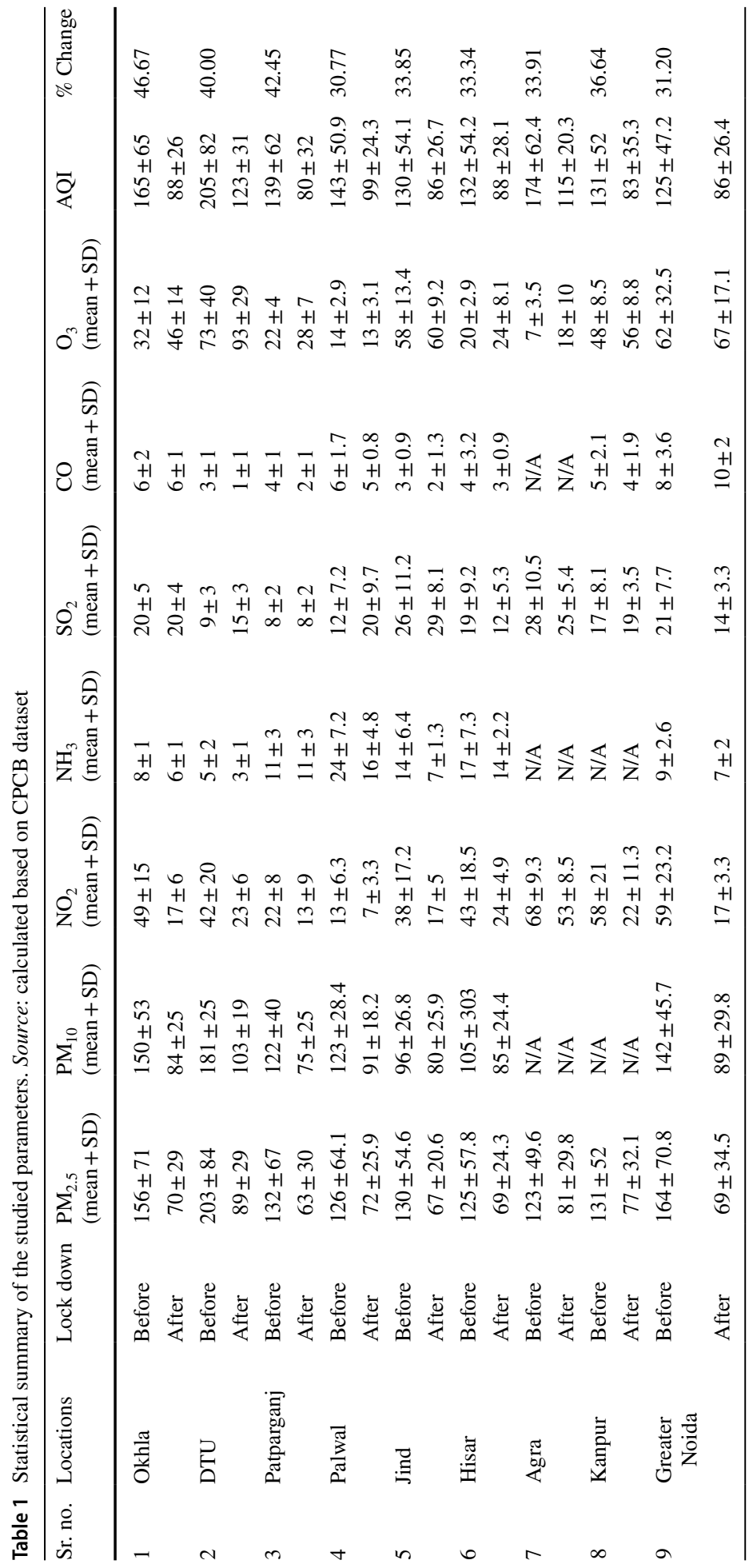




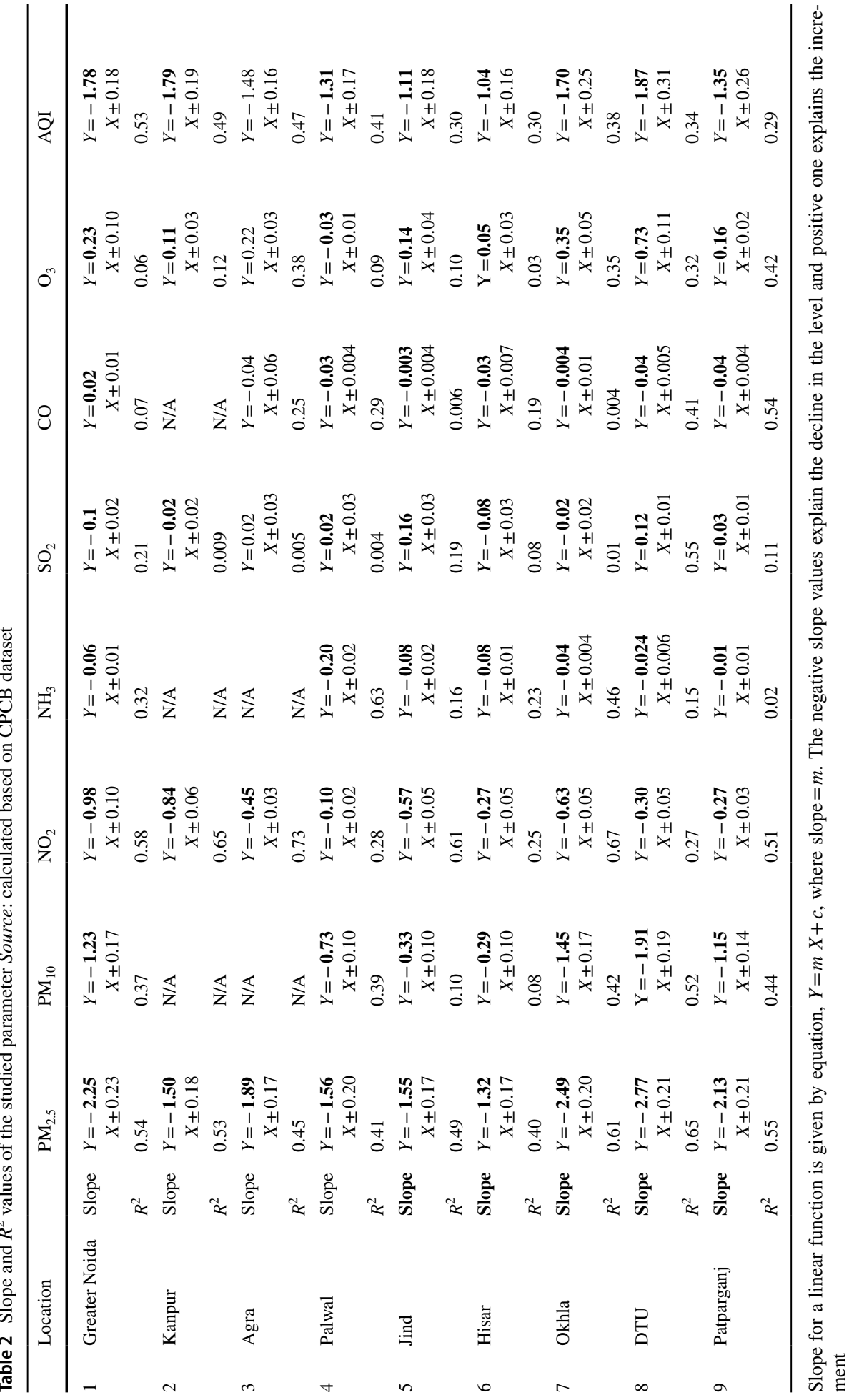


Table 3 Standard value of pollutants as set by CPCB (Akolkar 2016)

\begin{tabular}{llc}
\hline Sr. no. & Pollutant & $\begin{array}{l}\text { Standard } \\
\text { value }(\mu \mathrm{g} / \\
\left.\mathrm{m}^{3}\right)\end{array}$ \\
\hline 1 & Particulate matter 2.5 (microns) $[24 \mathrm{~h}]$ & 60 \\
2 & Particulate matter 10 (microns) $[24 \mathrm{~h}]$ & 100 \\
3 & Nitrogen dioxide $\left(\mathrm{NO}_{2}\right)[24 \mathrm{~h}]$ & 80 \\
4 & Ammonia $\left(\mathrm{NH}_{3}\right)[24 \mathrm{~h}]$ & 400 \\
5 & Sulphur dioxide $\left(\mathrm{SO}_{2}\right)[24 \mathrm{~h}]$ & 80 \\
6 & Carbon monoxide $(\mathrm{CO})[8 \mathrm{~h}]$ & 4000 \\
7 & Ozone $\left(\mathrm{O}_{3}\right)[8 \mathrm{~h}]$ & 100 \\
\hline
\end{tabular}

from non-agricultural sources are negligible; therefore, not much difference in the concentration levels was seen as Delhi is mostly covered with non-agricultural area (Behera et al. 2013; Mahato et al. 2020; Sutton et al. 1995). The effect of pollutants $\left(\mathrm{PM}_{2.5}, \mathrm{PM}_{10}, \mathrm{NO}_{2}\right.$ and $\mathrm{NH}_{3}$ ) on the AQI levels can be seen in Fig. 3d, and the highest to lowest value was 318 to 206 for DTU and PJ on 20 February 2020. After the implementation of lockdown on 2 April 2020, it declined to 83 (56) because of the concentrations of the pollutants (Table 4). The slope values $-1.87,-1.70$ and -1.35 are showing the overall reduction in the levels of AQI for before and after lockdown, due to less pollutant emission from anthropogenic sources. This increase in the $\mathrm{PM}_{2.5}, \mathrm{PM}_{10}, \mathrm{NO}_{2}, \mathrm{NH}_{3}$ and $\mathrm{AQI}$ is also reported by Srivastava et al. (2020). In Delhi, Mahato and Ghosh (2020) based on their observation summarized the difference in the levels of $\mathrm{PM}_{10}, \mathrm{PM}_{2.5}, \mathrm{SO}_{2}, \mathrm{NO}_{2}, \mathrm{CO}, \mathrm{O}_{3}$ and $\mathrm{NH}_{3}$ as $51.85 \%$, $53.11 \%, 17.97 \%, 52.68 \%, 30.35 \%, 0.78 \%$ and $12.33 \%$, respectively.

The slope of $\mathrm{SO}_{2}(0.12,-0.02$, and 0.03$)$ and $\mathrm{O}_{3}(0.73,0.35$, and 0.16$)$ curves show a slight increase for DTU, Okhla and PJ, respectively. The concentrations of $\mathrm{O}_{3}$ (Fig. 3b) increased primarily because of increase in atmospheric temperature in the northern region in between March to May (summers), which result in the photolysis/chemical production (Gaur et al. 2014). The ratio is especially increased after the lockdown because of lesser emission of $\mathrm{NO}$ which is converted into $\mathrm{NO}_{2}$ while being in the atmosphere via a similar phenomenon (Gorai et al. 2017; Mahato et al. 2020).

\subsection{Variation of atmospheric pollutants over Haryana}

The levels of $\mathrm{PM}_{2.5}$ in Haryana, before and after lockdown, ranged between 38 to $231 \mu \mathrm{g} /$ $\mathrm{m}^{3}$ and 26 to $130 \mu \mathrm{g} / \mathrm{m}^{3}, 39$ to $240 \mu \mathrm{g} / \mathrm{m}^{3}$ and 32 to $136 \mu \mathrm{g} / \mathrm{m}^{3}$ and 51 to $247 \mu \mathrm{g} / \mathrm{m}^{3}$ and 25 to $130 \mu \mathrm{g} / \mathrm{m}^{3}$ for Jind, Palwal and Hisar, respectively. The variation in $\mathrm{PM}_{10}$ before and after lockdown was seen 42 to $140 \mu \mathrm{g} / \mathrm{m}^{3}$ and 21 to $127 \mu \mathrm{g} / \mathrm{m}^{3}, 56$ to $171 \mu \mathrm{g} / \mathrm{m}^{3}$ and 56 to $121 \mu \mathrm{g} /$ $\mathrm{m}^{3}$ and 44 to $183 \mu \mathrm{g} / \mathrm{m}^{3}$ and 21 to $123 \mu \mathrm{g} / \mathrm{m}^{3}$, respectively. The minima and maxima values of $\mathrm{NO}_{2}$ before and after lockdown are given as 15 to $95 \mu \mathrm{g} / \mathrm{m}^{3}$ and10 to $26 \mu \mathrm{g} / \mathrm{m}^{3}, 7$ to $37 \mu \mathrm{g}$ / $\mathrm{m}^{3}$ and 1 to $19 \mu \mathrm{g} / \mathrm{m}^{3}$ and 18 to $132 \mu \mathrm{g} / \mathrm{m}^{3}$ and 16 to $38 \mu \mathrm{g} / \mathrm{m}^{3}$, respectively. Figure $4 \mathrm{~d}$ shows variation in the levels of $\mathrm{NH}_{3}$ fluctuating way below the standard level as given in Table 3, before and after lockdown from 7 to $28 \mu \mathrm{g} / \mathrm{m}^{3}$ and 5 to $10 \mu \mathrm{g} / \mathrm{m}^{3}, 14$ to $37 \mu \mathrm{g} / \mathrm{m}^{3}$ and 6 to 22 $\mu \mathrm{g} / \mathrm{m}^{3}$ and 1 to $28 \mu \mathrm{g} / \mathrm{m}^{3}$ and 10 to $19 \mu \mathrm{g} / \mathrm{m}^{3}$, respectively. CO levels in these areas are fluctuating around the standard levels (Table 3), before and after lockdown differing from 0.6 to $4.3 \mathrm{mg} / \mathrm{m}^{3}$ and 0.3 to $5.3 \mathrm{mg} / \mathrm{m}^{3}, 0.6$ to $9 \mathrm{mg} / \mathrm{m}^{3}$ and 3.7 to $7 \mathrm{mg} / \mathrm{m}^{3}$ and 1.2 to $15 \mathrm{mg} / \mathrm{m}^{3}$ and 1 to $5.1 \mathrm{mg} / \mathrm{m}^{3}$, respectively. All these pollutants were responsible for the decline in AQI of 


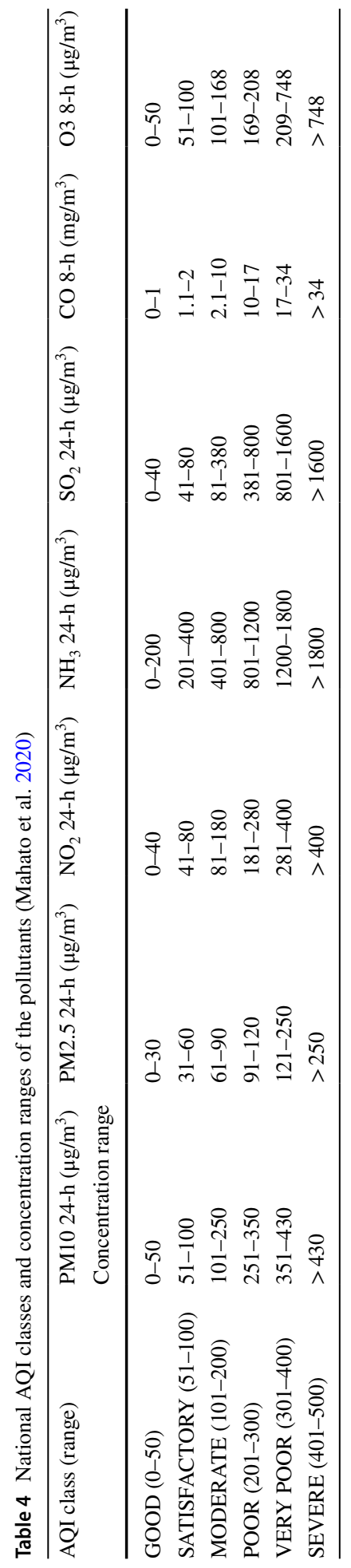


Haryana after implementation of lockdown. The AQI values before and after lockdown were recorded as 43 to 231 and 42 to 137,56 to 240 and 56 to 146 and 51 to 247 and 25 to 144 , respectively.

The levels of $\mathrm{SO}_{2}$ before and after lockdown varied from 9 to $56 \mu \mathrm{g} / \mathrm{m}^{3}$ and 11 to $44 \mu \mathrm{g}$ / $\mathrm{m}^{3}, 1$ to $25 \mu \mathrm{g} / \mathrm{m}^{3}$ and 3 to $41 \mu \mathrm{g} / \mathrm{m}^{3}$ and 5 to $50 \mu \mathrm{g} / \mathrm{m}^{3}$ and 3 to $23 \mu \mathrm{g} / \mathrm{m}^{3}$, respectively. $\mathrm{O}_{3}$ was found increasing from before to after lockdown 27 to $100 \mu \mathrm{g} / \mathrm{m}^{3}$ and 36 to $78 \mu \mathrm{g} / \mathrm{m}^{3}$, 7 to $19 \mu \mathrm{g} / \mathrm{m}^{3}$ and 4 to $22 \mu \mathrm{g} / \mathrm{m}^{3}$ and 15 to $28 \mu \mathrm{g} / \mathrm{m}^{3}$ and 14 to $47 \mu \mathrm{g} / \mathrm{m}^{3}$, respectively, over monitoring stations. Haryana being the agricultural region is mostly affected by factors like agriculture waste burning, extracting wheat and husk. The levels of particulate matter in the air were mainly due to the husk removal from the wheat (Kaushik et al. 2006). The maximum levels of $\mathrm{PM}_{2.5}$ and $\mathrm{PM}_{10}$ were recorded as $231 \mu \mathrm{g} / \mathrm{m}^{3}, 240 \mu \mathrm{g} / \mathrm{m}^{3}$ and $247 \mu \mathrm{g} / \mathrm{m}^{3}$ and $140 \mu \mathrm{g} /$ $\mathrm{m}^{3}, 171 \mu \mathrm{g} / \mathrm{m}^{3}$ and $183 \mu \mathrm{g} / \mathrm{m}^{3}$ for the stations. The lockdown affected the farmers by stopping their agricultural work for some duration, dropped the concentration levels of $\mathrm{PM}_{2.5}$ and $\mathrm{PM}_{10}$ up to $26 \mu \mathrm{g} / \mathrm{m}^{3}, 32 \mu \mathrm{g} / \mathrm{m}^{3}$ and $25 \mu \mathrm{g} / \mathrm{m}^{3}$ and $21 \mu \mathrm{g} / \mathrm{m}^{3}, 56 \mu \mathrm{g} / \mathrm{m}^{3}$ and $21 \mu \mathrm{g} / \mathrm{m}^{3}$, respectively. The arrival of a dust storm (mentioned earlier) and relaxation given to the farmers for harvesting the crops and other activities (Kharbikar et al. 2020) again increased the levels of $\mathrm{PM}_{2.5}$ and $\mathrm{PM}_{10}$ to $124 \mu \mathrm{g} / \mathrm{m}^{3}, 131 \mu \mathrm{g} / \mathrm{m}^{3}$ and $80 \mu \mathrm{g} / \mathrm{m}^{3}$ and $115 \mu \mathrm{g} / \mathrm{m}^{3}, 117 \mu \mathrm{g} / \mathrm{m}^{3}$ and $102 \mu \mathrm{g} / \mathrm{m}^{3}$, respectively, as on 16 April 2020. The overall decrease in particulate matter can be seen in the slopes of $\mathrm{PM}_{2.5}(-1.55,-1.56$ and -1.32$)$ and $\mathrm{PM}_{10}(-0.33,-0.73$ and -0.29$)$, respectively (Fig. 4a, b and Table 2).

$\mathrm{NO}_{2}$ and $\mathrm{NH}_{3}$ are mainly emitted by biomass burning, forest fires, vegetation, and agricultural crop emission, and fossil fuel combustion which is common in Haryana (Behera et al. 2013; Gadde et al. 2009; Srivastava et al. 2020). The highest values of $\mathrm{NO}_{2}\left(95 \mu \mathrm{g} / \mathrm{m}^{3}, 14 \mu \mathrm{g} /\right.$ $\mathrm{m}^{3}$, and $\left.61 \mu \mathrm{g} / \mathrm{m}^{3}\right)$ and $\mathrm{NH}_{3}\left(27 \mu \mathrm{g} / \mathrm{m}^{3}, 18 \mu \mathrm{g} / \mathrm{m}^{3}\right.$, and $\left.21 \mu \mathrm{g} / \mathrm{m}^{3}\right)$ were found on 19 February 2020 and 5 Mar 2020, respectively. However, the lowest levels for $\mathrm{NO}_{2}\left(13 \mu \mathrm{g} / \mathrm{m}^{3}, 7 \mu \mathrm{g} / \mathrm{m}^{3}\right.$, and $\left.18 \mu \mathrm{g} / \mathrm{m}^{3}\right)$ and $\mathrm{NH}_{3}\left(6 \mu \mathrm{g} / \mathrm{m}^{3}, 17 \mu \mathrm{g} / \mathrm{m}^{3}\right.$, and $\left.11 \mu \mathrm{g} / \mathrm{m}^{3}\right)$ were recorded as on 2 April 2020 and 9 April 2020, respectively. The slope of $\mathrm{NO}_{2}$ was reported as $-0.57,-0.10$, and -0.27 ; and of $\mathrm{NH}_{3}-0.08,-0.20$, and -0.08 (Fig. $4 \mathrm{c}$, $\mathrm{d}$ and Table 2). The $\mathrm{CO}$ concentrations were fluctuating near the standard value as given in Table 3. The slope values for $\mathrm{CO}$ were -0.003 , -0.03 , and -0.03 , which showed a decrease in the concentration of CO. The AQI slope values were $-1.11,-1.31$, and -1.04 of each station, respectively, showing the reduction in the level, and that may be due to decreased pollutant emission from anthropogenic activities. Before lockdown, the maximum AQI values were seen as 231, 240 and 247, and after the implementation of lockdown decreased to 42, 56, and 25, respectively. After lockdown, these values showed a sudden increase, i.e. 137, 140 and 138 on 16 April 2020 due to an increase in the levels of major pollutants, $\mathrm{PM}_{10}, \mathrm{PM}_{2.5}, \mathrm{NH}_{3}$ and $\mathrm{SO}_{2}$, because of dust storm (as mentioned earlier). $\mathrm{O}_{3}$ concentrations in the environment majorly depend on the temperature because of which it was seen fluctuating in the observation period by the calculated slope values of $0.14,-0.03$, and 0.05 , respectively. A similar fluctuation was also found in $\mathrm{SO}_{2}$ with slope values $0.16,0.02$, and -0.08 , respectively. Mahato and Ghosh (2020) specifically mentioned the average percentage difference in the levels of pollutants during first phase of lockdown (24 March 2020 to 6 April 2020) as 34.4\%, 34.6\%, 44.7\%, 41.1\%, 2.2\%, $20.1 \%$ and $6.7 \%$ change in the levels of $\mathrm{PM}_{10}, \mathrm{PM}_{2.5}, \mathrm{NO}_{2}, \mathrm{NH}_{3}, \mathrm{SO}_{2}, \mathrm{CO}$ and $\mathrm{O}_{3}$, respectively, over Jind.

\subsection{Variation of atmospheric pollutants over Uttar Pradesh}

The level of $\mathrm{PM}_{2.5}$ in UP before and after the lockdown varied from 47 to $233 \mu \mathrm{g} / \mathrm{m}^{3}$ and 41 to $150 \mu \mathrm{g} / \mathrm{m}^{3}$, 53 to $253 \mu \mathrm{g} / \mathrm{m}^{3}$ and 33 to $175 \mu \mathrm{g} / \mathrm{m}^{3}$ and 43 to $285 \mu \mathrm{g} / \mathrm{m}^{3}$ and 24 to 166 
$\mu \mathrm{g} / \mathrm{m}^{3}$ for Agra, Kanpur, and Greater Noida, respectively. Figure $6 \mathrm{~b}$ shows the variation in the levels of $\mathrm{PM}_{10}$ before and after lockdown from 56 to $250 \mu \mathrm{g} / \mathrm{m}^{3}$ and 26 to $160 \mu \mathrm{g}$ / $\mathrm{m}^{3}$ for Greater Noida. The levels of $\mathrm{NO}_{2}$ (Fig. 6c) fluctuated as before and after lockdown from 46 to $86 \mu \mathrm{g} / \mathrm{m}^{3}$ and 33 to $66 \mu \mathrm{g} / \mathrm{m}^{3} ; 28$ to $134 \mu \mathrm{g} / \mathrm{m}^{3}$ and 9 to $51 \mu \mathrm{g} / \mathrm{m}^{3}$; and 9 to 110 $\mu \mathrm{g} / \mathrm{m}^{3}$ and 12 to $24 \mu \mathrm{g} / \mathrm{m}^{3}$ for Agra, Kanpur and Greater Noida, respectively. Figure $6 \mathrm{~d}$ shows the variation in levels of $\mathrm{NH}_{3}$ before and after lockdown from 6 to $20 \mu \mathrm{g} / \mathrm{m}^{3}$ and 5 to $12 \mu \mathrm{g} / \mathrm{m}^{3}$ for Greater Noida. The CO levels before and after lockdown fluctuated from 1 to $9.5 \mathrm{mg} / \mathrm{m}^{3}$ and 1.5 to $8.8 \mathrm{mg} / \mathrm{m}^{3}$ and 3.1 to $13.8 \mathrm{mg} / \mathrm{m}^{3}$ and 5 to $14 \mathrm{mg} / \mathrm{m}^{3}$ for Agra and Greater Noida, respectively. The influence of the drop-in the levels of pollutants $\left(\mathrm{PM}_{2.5}\right.$, $\mathrm{PM}_{10}, \mathrm{NO}_{2}, \mathrm{NH}_{3}$ and $\mathrm{CO}$ ) can be seen in the form of AQI levels of UP, before lockdown and after lockdown which varied from 59 to 233 and 50 to $150 ; 53$ to 253 to 46 and 175; and 56 to 285 and 70 to 170 , respectively. $\mathrm{SO}_{2}$ variations before and after lockdown were recorded as 22 to $70 \mu \mathrm{g} / \mathrm{m}^{3}$ and 13 to $40 \mu \mathrm{g} / \mathrm{m}^{3} ; 9$ to $47 \mu \mathrm{g} / \mathrm{m}^{3}$ and 13 to $27 \mu \mathrm{g} / \mathrm{m}^{3}$; and 12 to $53 \mu \mathrm{g} / \mathrm{m}^{3}$ and 9 to $21 \mu \mathrm{g} / \mathrm{m}^{3}$, respectively. The $\mathrm{O}_{3}$ varies from 4 to $174 \mu \mathrm{g} / \mathrm{m}^{3}$ in UP.

The $\mathrm{PM}_{2.5}$ and $\mathrm{PM}_{10}$ being the major pollutants varied way above the standard values given in Table 3 as shown in Fig. 6a, b, respectively. The highest concentrations of $\mathrm{PM}_{2.5}$ were $228 \mu \mathrm{g} / \mathrm{m}^{3}, 253 \mu \mathrm{g} / \mathrm{m}^{3}$ and $228 \mu \mathrm{g} / \mathrm{m}^{3}$ over Agra, Kanpur and Greater Noida, respectively, and of $\mathrm{PM}_{10}$ was $212 \mu \mathrm{g} / \mathrm{m}^{3}$ over Greater Noida on 19 February 2020. The lockdown imposed in these regions reduced vehicular and industrial pollutions, showing a major decrease in concentration. On 3 April 2020, the values decreased to $43 \mathrm{mg} / \mathrm{m}^{3}, 34 \mathrm{mg} / \mathrm{m}^{3}$ and $35 \mathrm{mg} / \mathrm{m}^{3}$ for $\mathrm{PM}_{2.5}$ and $54 \mathrm{mg} / \mathrm{m}^{3}$ for $\mathrm{PM}_{10}$, respectively. In the third week of lockdown, the levels increased again to $111 \mathrm{mg} / \mathrm{m}^{3}, 118 \mathrm{mg} / \mathrm{m}^{3}, 120 \mathrm{mg} / \mathrm{m}^{3}$ and $120 \mathrm{mg} / \mathrm{m}^{3}$ as the government gave conditional relaxations. Overall, the slope is decreasing with the values $-1.89,-1.50$ and -2.25 and -1.20 , respectively, as given in Table $2 . \mathrm{NO}_{2}$ is not emitted directly into the environment but is formed from nitrogen atoms or NO upon reacting with oxygen. NO is found to occur as a result of anthropogenic activities like transportation (majorly), electricity generation, fossil fuel combustion, industrial emission (Popescu and Ionel 2010; Rai et al. 2011). Thus, after lockdown the values of the $\mathrm{NO}_{2}$ decreased giving a negative slope, the value being $-0.45,-0.84$, and -0.98 , respectively (Table 2). $\mathrm{NH}_{3}$ is largely emitted from agricultural sources and in small amounts from vehicle's motors and industries. Upon their halt, the level declined to give a slope value -0.06 in Greater Noida (Fig. 6d). $\mathrm{NH}_{3}$ is largely emitted from agricultural sources and in small amounts from vehicle's motors and industries. $\mathrm{CO}$ is mainly emitted by the incomplete combustion of biomass, fossil fuel, bio-fuel combustion, agricultural waste burning and industrial processes (Olivier et al. 1999). It is an unstable molecule and can easily react with oxygen to form $\mathrm{CO}_{2}$. If inhaled, $80-90 \%$ of $\mathrm{CO}$ is absorbed and binds with haemoglobin $(\mathrm{Hb})$ to form carboxyhaemoglobin (COHb), causing $\mathrm{CO}$ poisoning (Akolkar 2016). It combines with the oxygen in the blood and reduces the oxygen levels in the body, which can cause a slow death. The slope values of CO for Agra and Greater Noida were -0.04 and -0.05 , respectively, showing the decrease in CO level overall (Table 2). The AQI values were decreasing, as the calculated slope values are $-1.48,-1.79$, and -1.78 of each station, respectively, showing the reduction in the level of AQI resulting due to less pollutant emission from anthropogenic sources. The maximum AQI levels were recorded as 233, 214 and 285 before lockdown. After the lockdown was announced, the AQI levels decreased to values 83, 64 and 90 on 7 April 2020 as can be seen in Fig. 7d. A sudden increase to 127, 160 and 170 on 16 April 2020 was observed due to the dust storm (mentioned earlier).

$\mathrm{SO}_{2}$ and $\mathrm{O}_{3}$ are fluctuating under the national standard levels as given in Table 4. Oxygen from $\mathrm{NO}_{2}$ becomes free by the action of sunlight, and the free oxygen atom can react with $\mathrm{O}_{2}$ to form $\mathrm{O}_{3}$. The formation of $\mathrm{O}_{3}$ by other processes depends on the atmospheric 
temperature which has increased largely in northern India mainly due to chemical production/photochemical production during summers (Gaur et al. 2014) which is also our present range of observation (mentioned earlier). Thus, it resulted in a slope with values of 0.22 , 0.11 and 0.23 , respectively. The $\mathrm{SO}_{2}$ slope value is 0.02 for Agra showing an increment and -0.02 and -0.1 for Kanpur and greater Noida, respectively, showing a gradual deduction (Fig. 7a, c). The air mass back trajectory is also plotted to identify the source of pollutants from long-range transportation and regional origin of pollutants (Sect. 3.5). In Greater Noida, the average percent difference was observed as 54.4\%, 52\%, 64.1\% 17.9\%, 3.3\%, $43.9 \%$ and 32.4 in levels of $\mathrm{PM} 10, \mathrm{PM}_{2.5}, \mathrm{NO}_{2}, \mathrm{NH}_{3}, \mathrm{SO}_{2}, \mathrm{CO}$ and $\mathrm{O}_{3}$, respectively as reported by Mahato and Ghosh (2020) during the first phase of lockdown.

\subsection{Impact on air quality index (AQI)}

Figure 8 reveals that the significant decline in the AQI over all selected 9 stations with a dramatic impact attributed due to the implementation of nationwide stringent lockdown. Before lockdown, the average AQI was in poor range (AQI: 251 to 400) at DTU and Greater Noida and remaining others, i.e. Okhla, PJ, Jind, Hisar, Agra, Kanpur and Palwal, were moderately polluted (AQI: 101-250). However, after the implication of lockdown, the AQI in the moderately polluted zones was transformed into satisfactory air quality zones (AQI: 51 to 100) and poor air quality zones were changed into moderately polluted zones. The significant change in the AQI was observed for all the location, but in Okhla (46.67\%), PJ (42.45\%) and DTU (40.0\%), AQI was remarkably improved as compared to other locations such as Kanpur (36.64\%), Agra (33.91\%) Jind (33.85\%), Hisar (33.34\%), Greater Noida (31.20) and Palwal (30.77\%) during observation (Tables 1, 4). Mahato et al. (2020a) also reported a significant reduction of $59.4 \%$ and $52.92 \%$ during the lockdown period at industrial and transportation site over Delhi, whereas Srivastava et al. (2020) reported the AQI levels in the range of 137 to 210 before lockdown and AQI reduction up to 31.07

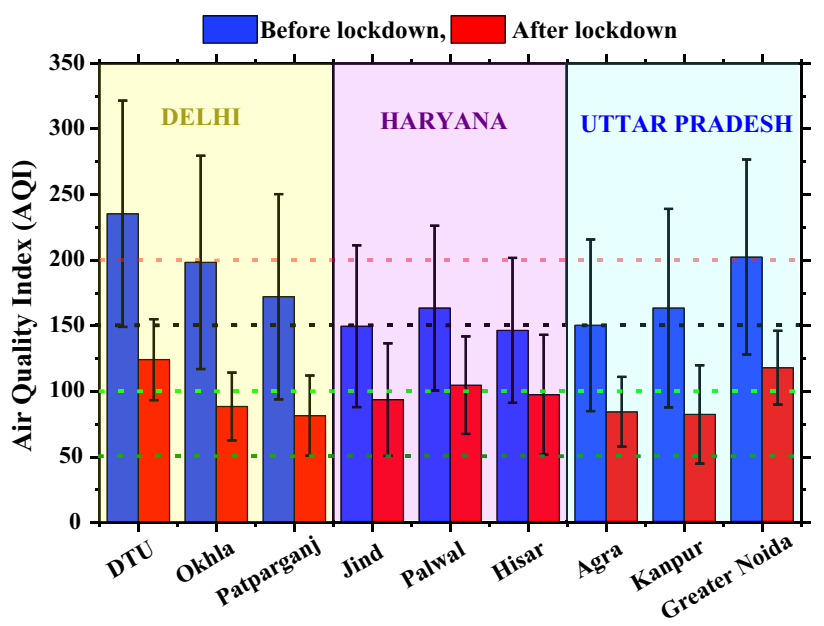

Fig. 8 Data showing the average variations in levels of AQI before (17 March 2020 to 24 March 2020) and after lockdown (25 March 2020 to 4 May 2020) in Delhi, Haryana and Uttar Pradesh. Source: Based on CPCB dataset 
to 75.50 after lockdown over three selected locations in Delhi. Mahato and Ghosh (2020) observed a drastic decline in the AQI of up to $22.6 \%$ to after lockdown over Jind (Haryana), whereas in Greater Noida, the AQI has improved by $53.9 \%$ and $43.6 \%$ after the first and second phase of lockdown.

\subsection{Air mass back trajectory (AMBT) analysis}

To understand the origin and transportation of pollutants, seven days' air mass back trajectories (AMBTs) for Delhi (Okhla, DTU, and PJ), Haryana (Jind, Palwal, and Hisar) and UP (Agra, Kanpur, and Greater Noida) were plotted at the altitude of $1000 \mathrm{~m}$ (above mean sea levels) as suggested by Koracin et al. (2011). The AMBTs for three locations in Delhi (Fig. 9a), Haryana (Fig. 9b) and two locations Agra and Noida are confined in UP, so these monitoring stations are considered as a single unit (Unit 1) as well as one location in UP, i.e. Kanpur is sufficient distantly located, so it is considered as another unit (Unit 2) in UP (Fig. 9c). To distinguish between long-range (LR) and short-range (SR) transportation events, dash and solid line representations are adopted. Figures 2, 3, 4, 5, 6, 7 and 8 indicate significant variation in the concentration of $\mathrm{PM}_{2.5}, \mathrm{PM}_{10}, \mathrm{NO}_{2}, \mathrm{NH}_{3}, \mathrm{SO}_{2}, \mathrm{O}_{3}, \mathrm{CO}$ and AQI after and before the lockdown. In the case of Delhi, the air mass (AM) coming from European, Gulf and African region to Afghanistan via Rajasthan and Punjab to Delhi is also influenced by the regional/local emission from Indo-Gangetic Plain and adjacent regions in both cases. The variations of AMBTs were also well defined and explained by Tiwari et al. (2017) for Delhi. In Figs. 2 and 3, there are peaks in pollution parameters and AQI on 20 February 2020, 27 February 2020, 26 March 2020, 16 April 2020 and 23 April 2020 which indicates the long-range transportation of air mass from Gulf, European and African countries as well as the transportation from Indian Gangetic Plain (IGP) on 19 February 2020 and 30 April 2020.

Similarly, in the case of Haryana (Fig. 9b), the AM originated from European, Gulf and African countries as well as Indian western neighbouring countries such as Afghanistan, western Pakistan via Rajasthan, and Punjab to Haryana on 27 February 2020, 2 April 2020, 23 April 2020 and 30 Ari 2020 via LR transportation and responsible for the significant change in over Haryana (Fig. 4 and 5). It also indicates the significant contribution from local emission entities located in National Capital Region (NCR) and Madhya Pradesh (Gautam et al. 2018) on 20 February 2020, 19 March 2020 and 26 April 2020.

But in the case of UP, the air mass is transported from European, Gulf and African countries such as Afghanistan, Tajikistan and western Pakistan on 27 February 2020, 19 March 2020, 9 April 2020, 16 April 2020 and 23 April 2020 via LR transportation of pollutants. However, AM is also coming from some Indian states such as Rajasthan, Punjab to Haryana and Maharashtra to both the locations, i.e. unit 1 and unit 2 (Satsangi et al. 2013; Gautam et al. 2018).

\section{Conclusion}

The COVID-19 pandemic forced many countries to implement full or partial lockdown, causing a substantial reduction in the anthropogenic activities due to being prohibited from outdoor invasion which resulted in less transportation and shutting down of industries. On the one hand, it caused people to suffer, whereas on the other hand, the environment benefitted from reduced emission of atmospheric pollutants. Initially, the levels of the 


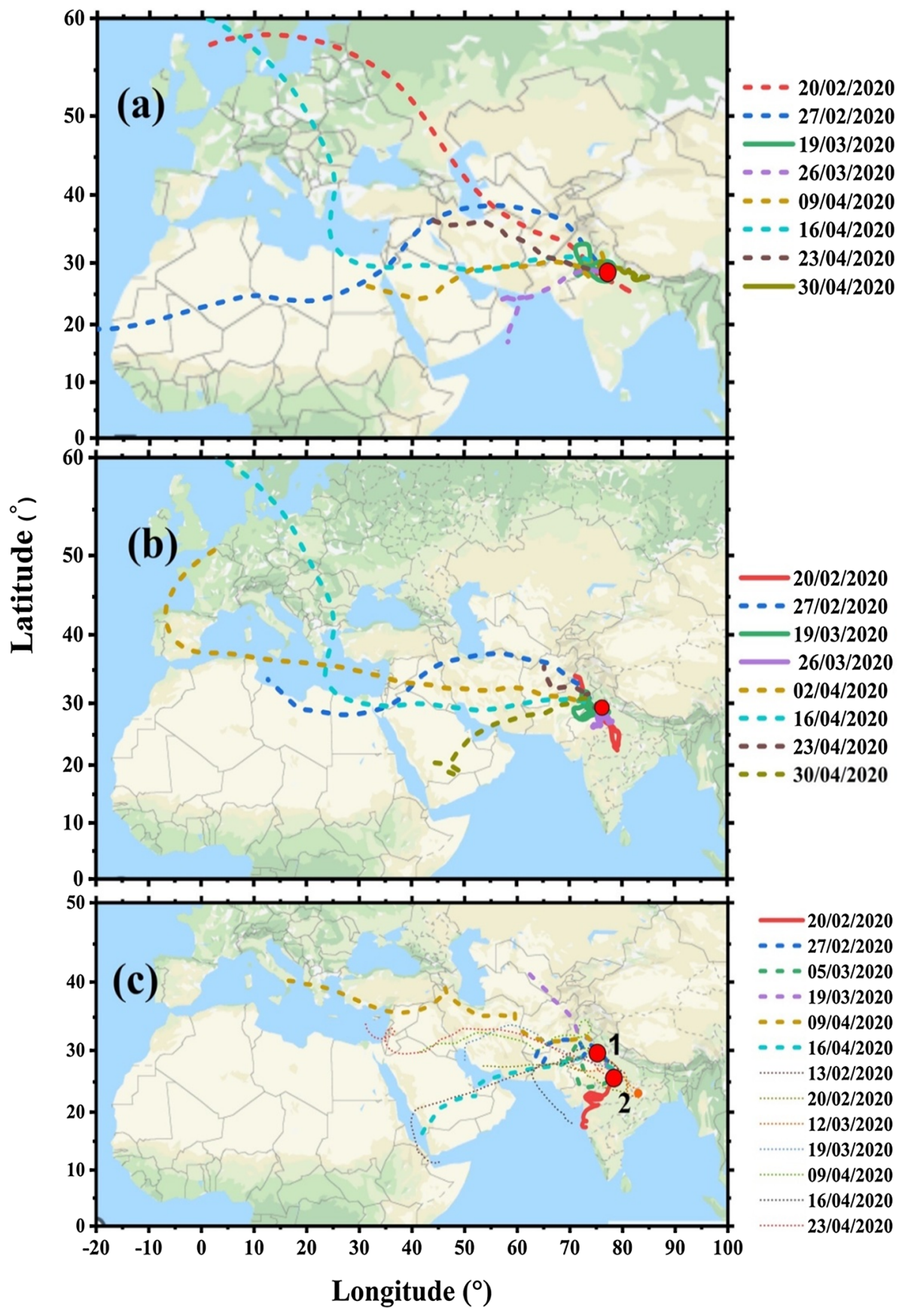

Fig. 9 Air mass trajectory of data showing the variations in levels of AQI and pollutants in Delhi (a), Haryana (b) and Uttar-Pradesh (c). Source: Based on NOAA (HYSPLIT) dataset 
considered pollutants $\mathrm{PM}_{2.5}, \mathrm{PM}_{10}, \mathrm{NO}_{2}, \mathrm{NH}_{3}$ and $\mathrm{CO}$ were well above the standard limits, which right after lockdown showed a sudden decline in the concentration level. Once the conditional relaxation was given, the levels again took a significant rise. The AQI is improved (reduced) up to 30-46.67\% after implication of lockdown. The levels of the particulate matter showed the most reduction in Delhi, followed by UP and Haryana because of lesser vehicles on road and reduced industrial emissions. $\mathrm{NO}_{2}$ levels have reduced mostly in UP, whereas a similar trend can be seen in Haryana and Delhi. The increase in the level of $\mathrm{SO}_{2}$ followed a similar trend in all the three regions. The level of $\mathrm{NH}_{3}$ reduced mostly in Haryana, followed by UP and Delhi as Haryana has most agricultural activity among the three regions which were halted. The level of $\mathrm{O}_{3}$ was enhanced and found highest in Delhi because of lesser greenery when compared to UP and Haryana, which resulted in higher atmospheric temperature favourable for $\mathrm{O}_{3}$ formation. The AMBT reveals that the air quality is potentially impacted by long-range and short-range/regional transportation of air masses, resulting in significant fluctuations in the major air pollutants. Considering the changes observed in air quality in such a short duration of inactivity, it can be conceived as an idea for future where the government can implement semi-lockdowns or even complete lockdowns. This will help maintain the improved quality of the air which will directly influence the health of environment and people.

\section{Limitations}

- The daily resolution of data was used for more precise detailing hourly data set which can be used to understand the diurnal variation.

- The missing data of some stations for some pollutants are due to the lack of instruments available there.

- Number of stations taken was only 3 for the whole state. Considering more stations might give better results.

- Only seven pollutants $\left(\mathrm{PM}_{2.5}, \mathrm{PM}_{10}, \mathrm{NO}_{2}, \mathrm{SO}_{2}, \mathrm{NH}_{3}, \mathrm{O}_{3}\right.$ and $\left.\mathrm{CO}\right)$ were considered. For more accurate detailing, more pollutants can be considered in the calculation of AQI.

\section{Future research directions}

- Proper instrumentation installation and regular calibration will allow more efficient studies.

- The spatial variation of pollutant with some location can performed over India.

- The further research must focus to calculate the timing of lockdown for different particular locations based on air moments, topography and background meteorological parameters.

\section{Compliance with ethical standards}

Conflict of interest The authors declare that they have no known competing financial interests or personalrelationships that could have appeared to influence the work reported in this paper. 


\section{References}

Akolkar. (2016). National air quality index. Central Pollution Control Board, 82, 1-44.

Anon. (2017) Uttar-Pradesh-Isfr-2017.Pdf.

Behera, S. N., Sharma, M., Aneja, V. P., \& Balasubramanian, R. (2013). Ammonia in the atmosphere: a review on emission sources, atmospheric chemistry and deposition on terrestrial bodies. Environmental Science and Pollution Research International, 20(11), 8092-8131. https://doi.org/10.1007/s11356-013-2051-9.

Culp, W. C. (2020). Coronavirus disease 2019. A and A Practice, 14(6), 01218.

Driggin, E., Madhavan, M. V., Bikdeli, B., Chuich, T., \& Harm, P. D. (2020). Since January 2020 Elsevier has created a COVID-19 resource centre with free information in English and Mandarin on the novel coronavirus COVID-19. The COVID-19 resource centre is hosted on elsevier connect, the Company' s Public News and Information." (January).

Erenstein, O. (2010). A comparative analysis of rice-wheat systems in Indian Haryana and Pakistan Punjab. Land Use Policy, 27(3), 869-879.

Gadde, B., Bonnet, S., Menke, C., \& Garivait, S. (2009). Air pollutant emissions from rice straw open field burning in India, Thailand and the Philippines. Environmental Pollution, 157(5), 1554-1558.

Gaur, A., Tripathi, S. N., Kanawade, V. P., Tare, V., \& Shukla, S. P. (2014). Four-year measurements of trace gases $\left(\mathrm{SO}_{2}, \mathrm{NO}_{\mathrm{x}}, \mathrm{CO}\right.$, and $\left.\mathrm{O}_{3}\right)$ at an urban location, Kanpur, in northern India. Journal of Atmospheric Chemistry, 71(4), 283-301. https://doi.org/10.1007/s10874-014-9295-8.

Gautam, S., \& Hens, L. (2020). SARS-CoV-2 pandemic in India: what might we expect? Environment, Development and Sustainability, 22(5), 3867-3869.

Gautam, S., Yadav, A., Pillarisetti, A., Smith, K., \& Arora, N. (2018, March). Short-term introduction of air pollutants from fireworks during Diwali in rural Palwal, Haryana, India: A case study. In IOP conference series earth and environmental science (pp. 1755-1315).

Gorai, A. K., Tchounwou, P. B., \& Mitra, G. (2017). Spatial variation of ground level ozone concentrations and its health impacts in an urban area in India. Aerosol and Air Quality Research, 17(4), 951.

Gottfredsson, M., Halldórsson, B. V., StefáJónsson, M., Kristjánsson, K., Kristinsson, K. G., Löve, A., et al. (2008). Lessons from the Past: Familial aggregation analysis of fatal pandemic influenza (Spanish Flu) in Iceland in 1918. Proceedings of the National Academy of Sciences of the United States of America, 105(4), 1303-1308. https://doi.org/10.1073/pnas.0707659105.

Güner, R., Hasanoğlu, I., \& Aktaş, F. (2020). COVID-19: Prevention and control measures in community. Turkish Journal of Medical Sciences, 50(1), 571-577. https://doi.org/10.3906/sag-2004-146.

Huang, C., Wang, Y., Li, X., Ren, L., Zhao, J., Hu, Y., et al. (2020). Clinical features of patients infected with 2019 novel coronavirus in Wuhan, China. The lancet, 395(10223), 497-506.

IMD. (2020a). Public weather bulletin. https://mausam.imd.gov.in/backend/assets/press_release_pdf/22-022020.pdf. Feb 22, 2020

IMD. (2020b). Public weather bulletin. https://mausam.imd.gov.in/backend/assets/press_release_pdf/PWB_0103-2020.pdf. Mar 01, 2020.

IMD. (2020c). Public weather bulletin. https://mausam.imd.gov.in/backend/assets/press_release_pdf/PWB_0703-2020.pdf. Mar 07, 2020.

Kaushik, C. P., Ravindra, K., Yadav, K., Mehta, S., \& Haritash, A. K. (2006). Assessment of ambient air quality in urban centres of Haryana (India) in relation to different anthropogenic activities and health risks. Environmental Monitoring and Assessment, 122(1-3), 27-40.

Kharbikar, H. L., Radhika, C., Naitam, R. K., Daripa, A., \& Malav, L. (2020). Consequences of COVID-19 pandemic and lockdown on food and agribusiness sector in india. Food and scientific reports, 1(6), 13-18.

Kim, S., Hong, K. H., Jun, H., Park, Y. J., Park, M., \& Sunwoo, Y. (2014). Effect of precipitation on air pollutant concentration in Seoul, Korea. Asian Journal of Atmospheric Environment, 8(4), 202-211. https://doi. org/10.5572/ajae.2014.8.4.202.

Koracin, D., Vellore, R., Lowenthal, D. H., Watson, J. G., Koracin, J., McCord, T., et al. (2011). Regional source identification using lagrangian stochastic particle dispersion and HYSPLIT backward-trajectory models. Journal of the Air and Waste Management Association, 61(6), 660-672.

Mahato, S., \& Ghosh, K. G. (2020). Short-term exposure to ambient air quality of the most polluted Indian cities due to lockdown amid SARS-CoV-2. Environmental Research, 188, 109835. https://doi.org/10.1016/j. envres.2020.109835.

Mahato, S., Pal, S., \& Ghosh, K. G. (2020). Effect of lockdown amid COVID-19 pandemic on air quality of the megacity Delhi, India. Science of the Total Environment, 730, 139086. https://doi.org/10.1016/j.scito tenv.2020.139086.

Mitra, P., Misra, S., \& Sharma, P. (2020). COVID-19 pandemic in India: What lies ahead. Indian Journal of Clinical Biochemistry, 1.

MSME. (2012). State industrial profile. Msme 132001.

MSME. (2015). State industrial profile. Msme 132001. 
NCML. (2019). Basmati crop survey report. Basmati Export Development Foundation, Apeda, New Delhi. https://apeda.gov.in/apedawebsite/Announcements/Basmati_Crop_survey_Report_1_Season_2019. pdf.

NDTV (2020). Delhi's air quality may deteriorate due to dust storms: Report. https://www.ndtv.com/delhi -news/delhis-air-quality-may-deteriorate-due-to-dust-storms-report-2211965. Accessed June 6, 2020.

Olivier, J. G., Bloos, J. P. J., Berdowski, J. J., Visschedijk, A. J., \& Bouwman, A. F. (1999). A 1990 global emission inventory of anthropogenic sources of carbon monoxide on $1 \times 1$ developed in the framework of EDGAR/GEIA. Chemosphere-Global Change Science, 1(1-3), 1-17.

Popescu, F., \& Ioana, I. (2010). Anthropogenic air pollution sources, Air Quality. Air quality. http://www.intec hopen.com/books/air-quality/anthropogenic-air-pollution-sources.

Potter, C. W. (2001). A history of influenza. Journal of applied microbiology, 91(4), 572-579. https://doi.org/10 .1046/j.1365-2672.2001.01492.x.

Rai, R., Rajput, M., Agrawal, M., \& Agrawal, S. B. (2011). Gaseous air pollutants: A review on current and future trends of emissions and impact on agriculture. Journal of Scientific Research, 55(771), 1.

Mitra, P., Misra, S., \& Sharma, P. (2020). COVID-19 pandemic in india: what lies ahead. Indian Journal of Clinical Biochemistry, 1, 9-11. https://doi.org/10.1007/s12291-020-00886-6.

Satsangi, A., Pachauri, T., Singla, V., Lakhani, A., \& Kumari, K. M. (2013). Water soluble ionic species in atmospheric aerosols: Concentrations and sources at Agra in the Indo-Gangetic Plain (IGP). Aerosol and Air Quality Research, 13(6), 1877-1889.

Sawlani, R., Agnihotri, R., Sharma, C., Patra, P. K., Dimri, A. P., Ram, K., et al. (2019). The severe Delhi SMOG of 2016: A case of delayed crop residue burning, coincident firecracker emissions, and atypical meteorology. Atmospheric Pollution Research, 10(3), 868-879.

Sharma, S., Zhang, M., Gao, J., Zhang, H., \& Kota, S. H. (2020). Effect of restricted emissions during COVID19 on air quality in India. Science of the Total Environment, 728, 138878.

Shereen, M. A., Khan, S., Kazmi, A., Bashir, N., \& Siddique, R. (2020). COVID-19 infection: Origin, transmission, and characteristics of human coronaviruses. Journal of Advanced Research, 24, 91-98.

Singh, R. P., \& Chauhan, A. (2020). Impact of lockdown on air quality in India during COVID-19 pandemic. Air Quality, Atmosphere and Health, 13(2020), 921-928. https://doi.org/10.1007/s11869-020-00863-1.

Singhal, T. (2020). A review of coronavirus disease-2019 (COVID-19). Indian Journal of Pediatrics, 87(4), 281-286.

Srivastava, S., Kumar, A., Bauddh, K., Gautam, A. S., \& Kumar, S. (2020). 21-day lockdown in India dramatically reduced air pollution indices in Lucknow and New Delhi, India. Bulletin of environmental contamination and toxicology, 105(1), 9-17. https://doi.org/10.1007/s00128-020-02895-w.

Stein, A. F., Draxler, R. R., Rolph, G. D., Stunder, B. J., Cohen, M. D., \& Ngan, F. (2015). NOAA's HYSPLIT atmospheric transport and dispersion modeling system. Bulletin of the American Meteorological Society, 96(12), 2059-2077.

Sutton, M. A., Place, C. J., Eager, M., Fowler, D., \& Smith, R. I. (1995). Assessment of the magnitude of ammonia emissions in the United Kingdom. Atmospheric Environment, 29(12), 1393-1411.

Tanvir, A., Khokhar, M. F., Javed, Z., Sandhu, O., Mustansar, T., \& Shoaib, A. (2019). Spatiotemporal evolution of atmospheric ammonia columns over the Indo-Gangetic plain by exploiting satellite observations. Advances in Meteorology, 2019, 11. https://doi.org/10.1155/2019/7525479.

Tiwari, S., Dumka, U. C., Gautam, A. S., Kaskaoutis, D. G., Srivastava, A. K., Bisht, D. S., et al. (2017). Assessment of $\mathrm{PM}_{2.5}$ and PM10 over Guwahati in Brahmaputra River Valley: Temporal evolution, source apportionment and meteorological dependence. Atmospheric Pollution Research, 8(1), 13-28.

UIAI-GOI 2017. (2020). Govt. of India. State/UT wise Aadhaar Saturation. In Unique Identification Authority of India 2017. Accessed June 12, 2020.

WHO. (2020). Novel Corona Virus Disease (COVID-19) (March 22, 2020). WHO, https://www.who.int/docs/ default-source/wrindia/situation-report/india-situation-report-8.pdf?sfvrsn=cd671813_2. Accessed May $19,2020$.

Zhu, Y., Xie, J., Huang, F., \& Cao, L. (2020). Association between short-term exposure to air pollution and COVID-19 infection: Evidence from China. Science of the Total Environment, 727(2019), 138704. https:// doi.org/10.1016/j.scitotenv.2020.138704.

Zoran, M. A., Savastru, R. S., Savastru, D. M., \& Tautan, M. N. (2020). Assessing the relationship between surface levels of $\mathrm{PM}_{2.5}$ and PM10 particulate matter impact on COVID-19 in Milan, Italy. Science of the Total Environment, 738, 139825. https://doi.org/10.1016/j.scitotenv.2020.139825.

Publisher's Note Springer Nature remains neutral with regard to jurisdictional claims in published maps and institutional affiliations. 


\section{Affiliations}

Alok Sagar Gautam ${ }^{1} \cdot$ Nikhilesh Kumar Dilwaliya $^{2} \cdot$ Ayushi Srivastava $^{3}$. Sanjeev Kumar ${ }^{1} \cdot K^{\prime}$ uldeep Bauddh ${ }^{4} \cdot$ Devendraa Siingh ${ }^{5} \cdot$ M. A. Shah ${ }^{2} \cdot K_{a r a n} S_{i n g h}{ }^{1}$. Sneha Gautam ${ }^{6}$

1 Department of Physics, Hemvati Nandan Bahuguna Garhwal University, Srinagar, Garhwal, Uttarakhand 246174, India

2 Department of Physics, National Institute of Technology Srinagar, Hazarathbal, Srinagar, Jammu and Kashmir 190006, India

3 Department of Microbiology, Chaudhary Charan Singh University, Meerut, Uttar Pradesh 250001, India

4 Department of Environmental Sciences, Central University of Jharkhand, Ranchi 835205, India

5 Indian Institute of Tropical Meteorology, Dr. Homi Bhabha Road, Pashan, Pune 411008, India

6 Karunya Institute of Technology and Sciences, Deemed University, Karunya Nagar, Coimbatore, Tamil Nadu 641114, India 